\title{
Synthesis of Azide-Modified Chondroitin Sulfate Precursors: Substrates for "Click"- Conjugation with Fluorescent Labels and Oligonucleotides
}

Satish Jadhav, ${ }^{*}, \dagger, \ddagger$ Vijay Gulumkar, ${ }^{\dagger}$ Prasannakumar Deshpande, ${ }^{\S}$ Eleanor T. Coffey, ${ }^{\S}$ Harri Lönnberg, ${ }^{\dagger}$ and Pasi Virta*,†

${ }^{\dagger}$ Department of Chemistry, University of Turku, Vatselankatu 2, FI 20014 Turku, Finland

${ }^{\ddagger}$ Department of Cellular and Molecular Medicine, School of Medicine, University of California, San Diego, La Jolla, California 92093, United States

${ }^{\S}$ Turku Centre for Biotechnology, University of Turku, Åbo Akademi University, Tykistökatu 6, FI 20520 Turku, Finland

\section{Supporting Information}

ABSTRACT: Azidopropyl-modified precursors of chondroitin sulfate (CS) tetrasaccharides have been synthesized, which, after facile conversion to final CS structures, may be conjugated with alkyne-modified target compounds by a one-pot "click"-ligation. RP HPLC was used for the monitoring of the key reaction steps (protecting group manipulation and sulfation) and purification of the CS precursors (as partially protected form, bearing the $O-\mathrm{Lev}$, $O$-benzoyl, and $\mathrm{N}$-trichloroacetyl groups and methyl esters). Subsequent treatments with aqueous $\mathrm{NaOH}$, concentrated ammonia, and acetic anhydride (i.e., global deprotection and acetylation of the galactosamine units) converted the precursors to final CS structures. The azidopropyl group was exposed to a strainpromoted azide-alkyne cycloaddition (SPAAC) with a dibenzylcyclooctyne-modified carboxyrhodamine dye to give labeled CSs. Conjugation with a 5'-cyclooctyne-modified oligonucleotide was additionally carried out to show the applicability of the precursors for the synthesis of biomolecular hybrids.
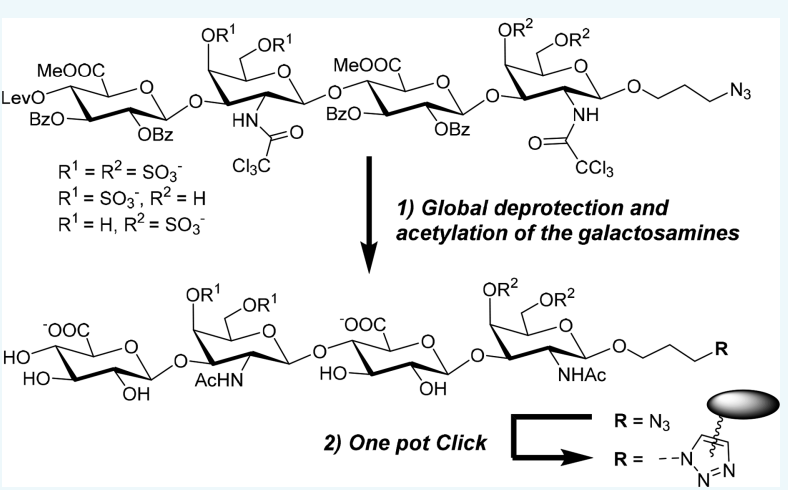

\section{INTRODUCTION}

Chondroitin sulfate (CS) is a linear sulfated polysaccaharide that plays pivotal roles in many biological processes such as cell division, neuronal development, viral invasion, cancer metastasis, and spinal cord injury. ${ }^{1-5} \mathrm{CS}$ is composed of repeating $\beta$ D-glucuronic acid (GlcA) and $N$-acetyl- $\beta$-D-galactosamine (GalNAc) units arranged in the sequence by GlcA- $\beta(1 \rightarrow 3)$ GalNAc- $\beta(1 \rightarrow 4)$ glycosidic bonds with variable high and low sulfation patterns. The highly sulfated regions with a specific arrangement of the sulfate groups define the binding motifs for certain proteins (for example neurotrophins, selectins, chemokines, and midkine). ${ }^{6,7}$ Because of the biological activities of $\mathrm{CS}$, it has a great potential in the drug development related to malignant tumors, multiple sclerosis, and neuronal degeneration processes, ${ }^{8}$ for example. Several research groups have reported synthetic ${ }^{9-17}$ or semisynthetic ${ }^{18,19}$ procedures for the preparation of different CS derivatives. Even a solid-phase approach has been utilized. ${ }^{20}$ Biological activity of synthetic CS di-, tetrasaccharide derivatives, ${ }^{21-29}$ including CS-based glycomimetic polymers, ${ }^{28,29}$ and glycopeptides, $^{30,31}$ has been extensively studied. In addition, CS-modified cell-surface glycal engineering $^{30}$ and CS-based microarrays ${ }^{32,33}$ have been reported. For the drug delivery purposes, nanoparticles and liposomes ${ }^{34}$ carrying genes ${ }^{35}$ and anticancer drugs ${ }^{36}$ have been coated with polymeric CS to provide targeted delivery via CD44 (a cell surface receptor)-mediated endocytosis.

Alternative procedures for the preparation of structurally well-defined, appropriately sulfated, homogeneous CS polysaccharide derivatives are still demanding. Only a micromolescale synthesis of conjugated or labeled CSs is usually required to give sufficient amounts of compounds for the biological activity studies. Multistep miniature manipulation of an oligosaccharide may be complex, however, especially if the product is strongly hydrophilic and lacks a chromophore. Therefore, It may be beneficial to design appropriately protected and UV-detectable precursors, which may be readily purified by RP HPLC and converted then via quantititative global deprotection step to the desired products that may be finally "fished out" by an appropriate label or a chromophoric conjugate group. ${ }^{37,38}$ In the present study, azidopropylmodified CS tetrasaccharide precursors (18, 21, 23, and 27) have been synthesized on a $6 \mu \mathrm{mol}$ scale. The precursors could

Received: May 8, 2018

Revised: June 1, 2018

Published: June 1, 2018 
be homogenized by RP HPLC and quantitatively converted to final CS structures prior to a one-pot "click"-ligation with alkyne-modified target compounds. Tetrasaccharide $\mathbf{1 6}$ acted as a general starting material for the synthesis of 18, 21, and 23 . Different sulfation patterns at C4 and C6 sites of the GalNAc residues (18 vs 21 ) were obtained by utilizing an orthogonality of the benzylidene and chloroacetyl/acetyl protections. The key reaction steps, that is, the protecting group manipulation and sulfation, could be monitored by RP HPLC. The homogenized CS precursors $(18,21,23$, and 27, bearing the $O$-Lev, $O$ benzoyl, and $\mathrm{N}$-trichloroacetyl groups and methyl esters) were converted to final CS structures by subsequent treatments with aqueous $\mathrm{NaOH}$, concentrated ammonia, and acetic anhydride (i.e., the global deprotection and acetylation of the galactosamine units) and exposed then to a strain-promoted azidealkyne cycloaddition (SPAAC) with a dibenzylcyclooctynmodified carboxyrhodamine dye to give labeled CSs 24-26 and 29. Conjugation with a 5 -cyclooctyne-modified oligonucleotide was additionally carried out to show the applicability of the precursors $(18,21,23)$ for the synthesis of biomolecular hybrids.

\section{RESULTS AND DISCUSSION}

Synthesis of Disaccharide Glycosyl Acceptor 10 and Donor 12. Appropriately protected disaccharide acceptor and donor (10 and 12) were first prepared as outlined in Schemes 1

Scheme 1. Synthesis of Glycosyl Acceptor $7^{a}$

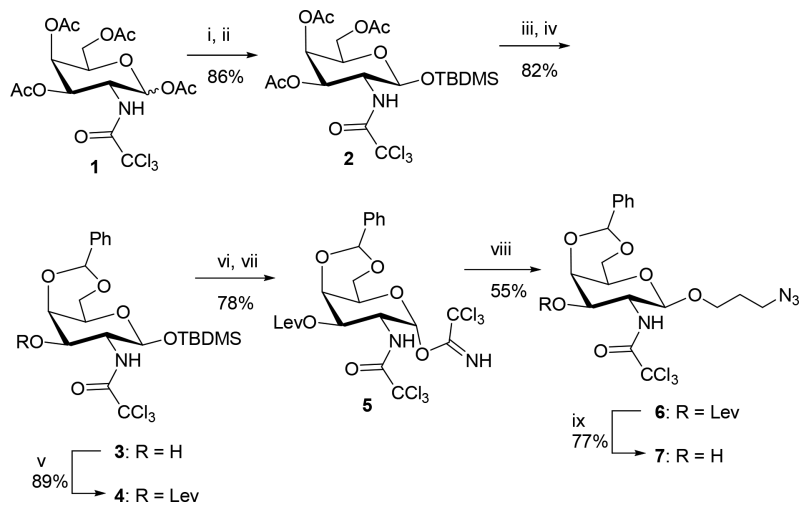

${ }^{a}$ Reagents and conditions: (i) hydrazine acetate, DMF; (ii) TBDMSCl, imidazole, DMF, room temperature; (iii) $0.1 \mathrm{~mol} \mathrm{~L}^{-1}$ $\mathrm{NaOMe}$ in $\mathrm{MeOH}$, room temperature; (iv) $\mathrm{PhCH}(\mathrm{OMe})_{2}, p$-TSA, acetonitrile, room temperature; (v) levulinic acid, DCC, DMAP, $\mathrm{CH}_{2} \mathrm{Cl}_{2}$, room temperature; (vi) $\mathrm{Et}_{3} \mathrm{~N} \cdot 3 \mathrm{HF}$, THF, room temperature; (vii) $\mathrm{CCl}_{3} \mathrm{CN}, \mathrm{DBU}, \mathrm{CH}_{2} \mathrm{Cl}_{2}, 0^{\circ} \mathrm{C}$; (viii) 3-azidopropan-1-ol, TMSOTf, $\mathrm{CH}_{2} \mathrm{Cl}_{2},-30^{\circ} \mathrm{C}$; (ix) hydrazine acetate, pyridine, room temperature.

and 2. tert-Butyldimethylsilyl 4,6-O-benzylidene-2-deoxy-3-Olevulinoyl-2-trichloroacetamido- $\beta$-D-galactopyranoside (4) and 3-azidopropyl (4,6-benzylidene-2-deoxy-2-trichloroacetamido$\beta$-D-galactopyranoside) (7) were synthesized from 1,3,4,6tetra- $O$-acetyl- $N$-trichloroacetyl- $\beta$-D-galactosamine (1)(Scheme 1 ) and they were glycosylated with (methyl 2,3-di-O-benzoyl-4$O$-levulinoyl- $\beta$-D-glucopyranosyluronate) trichloroacetimidate $(8)^{39}$ using TMSOTf as a catalyst (Scheme 2). Disaccharides 9 and 11 were obtained in acceptable 66 and $73 \%$ yields, respectively. The TBDMS group of 11 was removed by a treatment with $\mathrm{Et}_{3} \mathrm{~N} \cdot 3 \mathrm{HF}$ and the exposed anomeric hydroxyl group was converted to $O$-trichloroacetimidate (12). The
Scheme 2. Synthesis of Glycosyl Acceptor 10 and Glycosyl Donor $12^{a}$

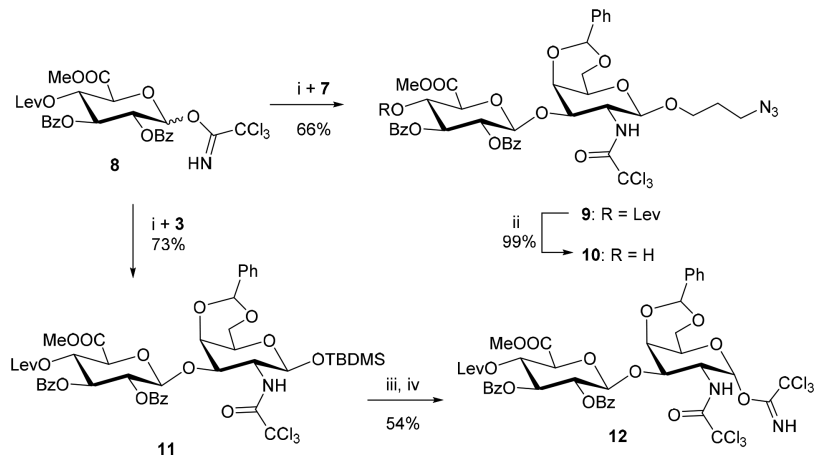

${ }^{a}$ Reagents and conditions: (i) TMSOTf, $\mathrm{CH}_{2} \mathrm{Cl}_{2}, 0^{\circ} \mathrm{C}$; (ii) hydrazine acetate, pyridine, room temperature; (iii) $\mathrm{Et}_{3} \mathrm{~N} \cdot 3 \mathrm{HF}$, $\mathrm{THF}$, room temperature; (iv) $\mathrm{CCl}_{3} \mathrm{CN}, \mathrm{DBU}, \mathrm{CH}_{2} \mathrm{Cl}_{2}, 0^{\circ} \mathrm{C}$.

levulinoyl group of 9 was removed with hydrazine hydrate to give disaccharide glycosyl acceptor $\mathbf{1 0}$.

Synthesis of Fully Protected CS-Tetrasaccharide Precursors 13 and 15. Unexpected stereochemical outcome of glycosylations with 4,6-O-benzylidene protected 2-deoxy-2trichloroacetamido-D-galactosyl trichloroacetimidate acceptors has been reported. ${ }^{40}$ Glycosylation of simple alcohols with monomeric $N$-acyl galactosamines may give the expected $\beta$ anomer as a major product (e.g., synthesis of $\mathbf{6}$ from $\mathbf{5}$, Scheme $2)$, but the extent of the $\alpha$-anomer may become significant in glycosylation of D-glucuronic acid-derived acceptors and with disaccharidic $N$-acyl galactosamine donors. This has been attributed to unfavorable interactions in the transition state between the 4,6-benzylidene group and the approaching Dglucuronic derived acceptors. ${ }^{41}$ As outlined in Scheme 3,

Scheme 3. Synthesis of Chondroitin Sulfate Precursors 13 and $15^{a}$
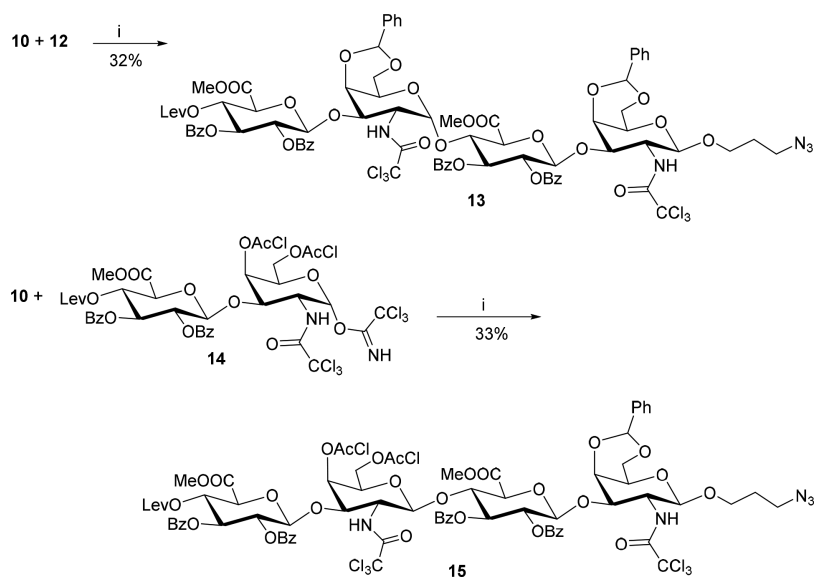

${ }^{a}$ Reagents and conditions: (i) TMSOTf, $\mathrm{CH}_{2} \mathrm{Cl}_{2},-30^{\circ} \mathrm{C}$.

glycosylation of 10 with disaccharide donor 12 gave tetrasaccharide 13 with an $\alpha$-glycosidic bond in $32 \%$ isolated yield and only a substantial amount of $\beta$-glycosylation was observed. The preference for the $\beta$-anomer may be increased by replacing the benzylidene group to two acyl protections. ${ }^{41}$ Glycosylation of $\mathbf{1 0}$ with previously reported disaccharide donor $14^{14}$ (bearing 4,6-O-chloroacetyl protections instead of the benzylidene group) gave tetrasaccharide 15 with the 
Scheme 4. Synthesis of Chondroitin Sulfate Precursors (18-23) and RP HPLC Monitoring of the Reactions ${ }^{a}$
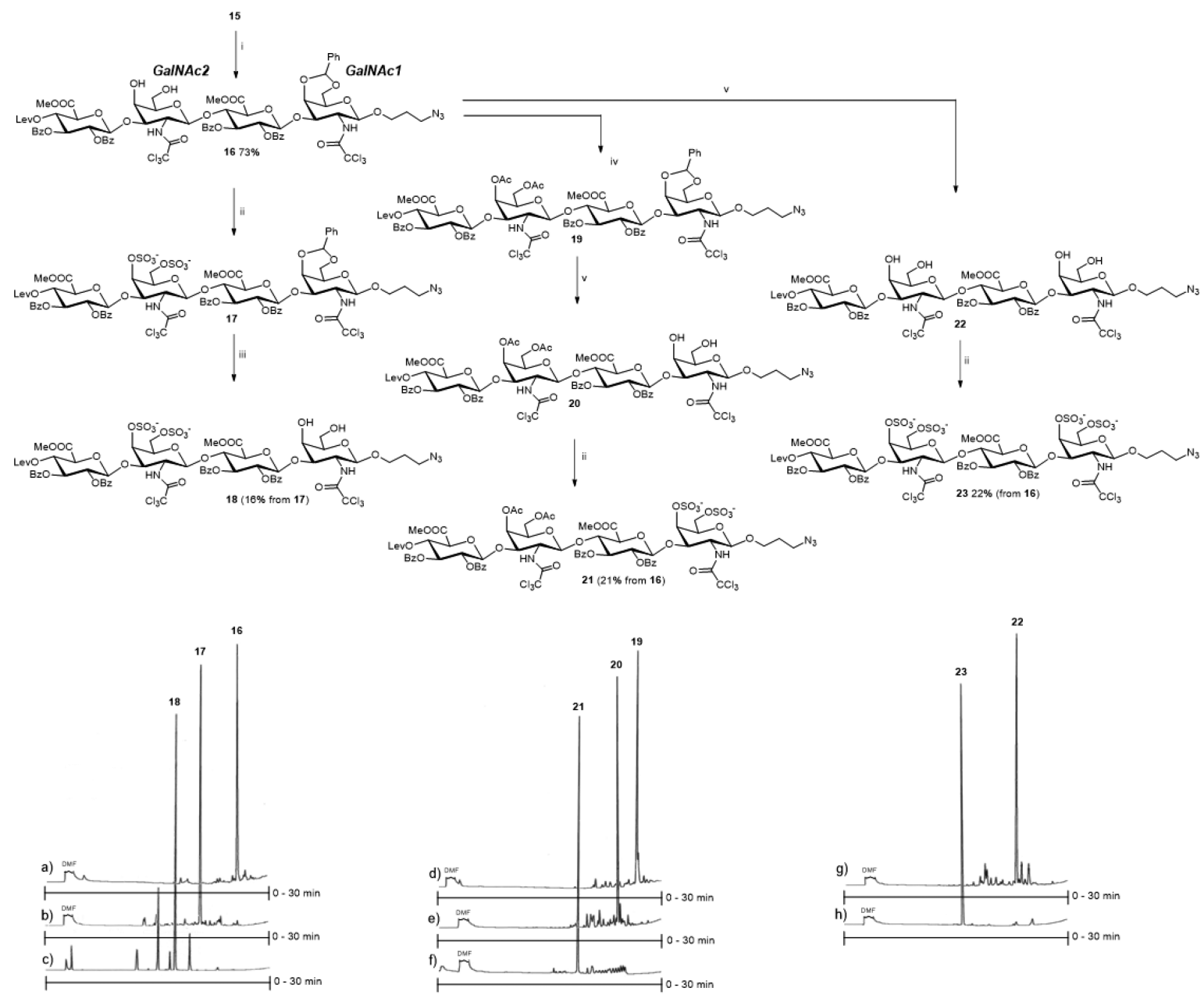

${ }^{a}$ Reagents and conditions: (i) thiourea, pyridine-EtOH (1:1, v/v), $2 \mathrm{~h}$ at $80^{\circ} \mathrm{C}$; (ii) $\mathrm{SO}_{3} \cdot \mathrm{TMA}, \mathrm{DMF}$, overnight at $50^{\circ} \mathrm{C}$; (iii) $0.1 \%$ aq TFA, $5 \mathrm{~h}$ at r.t.; (iv) $\mathrm{Ac}_{2} \mathrm{O}$, pyridine, overnight at r.t.; (v) $80 \%$ aq $\mathrm{AcOH}, 1 \mathrm{~h}$ at $100^{\circ} \mathrm{C}$. RP HPLC conditions: an analytical RP HPLC column $(250 \times 4.6 \mathrm{~mm}, 5$ $\mu \mathrm{m}$ ), flow rate: $1.0 \mathrm{~mL} \mathrm{~min}^{-1}$, detection at $220 \mathrm{~nm}$, profiles a, d, and g: a gradient elution from 20 to $100 \% \mathrm{MeCN}$ in $0.1 \mathrm{~mol} \mathrm{~L}{ }^{-1}$ aqueous triethylammonium acetate $(0-25 \mathrm{~min})$, profiles $\mathrm{b}, \mathrm{c}, \mathrm{e}, \mathrm{f}$, and $\mathrm{h}$ : a gradient elution from 0 to $50 \% \mathrm{MeCN}$ in $0.1 \mathrm{~mol} \mathrm{~L}^{-1}$ aqueous triethylammonium acetate $(0-25 \mathrm{~min})$, then from $50 \%$ to $100 \% \mathrm{MeCN}$ in $0.1 \mathrm{~mol} \mathrm{~L}^{-1}$ aqueous triethylammonium acetate $(25-30$ min), profiles of crude product (16-23) mixtures described.

expected $\beta$-glycosidic bond in a $33 \%$ isolated yield (the major byproduct was hydrolyzed 14).

Protecting Group Manipulation and Sulfation To Obtain CS-Tetrasaccharide Precursors 18, 21, and 23 with Different Sulfation Pattern. The chloroacetyl groups of 15 were selectively removed with a mixture of thiourea, pyridine, and ethanol, and the obtained tetrasaccharide 16 was used as a shared starting material for $\mathbf{1 8}, \mathbf{2 1}$, and $\mathbf{2 3}$ (Scheme 4, note the definitions of GalNAc-1 and GalNAc- 2 to clarify the readability of the text). The required protecting group manipulation and sulfation were carried out on a $6 \mu \mathrm{mol}$ scale and the key reaction steps were monitored by RP HPLC (see RP HPLC profiles of the crude product mixtures: $a-h /$ Scheme 4). Orthogonality of the benzylidene and chloroacetyl/ acetyl protections was utilized to obtain different sulfation patterns at $\mathrm{C} 4$ and $\mathrm{C} 6$ sites of the $\mathrm{N}$-acetyl galactosamine residues (GalNAc-1 and GalNAc-2, 18 vs 21 ). To obtain 18 , the exposed 4- and 6-OH groups (GalNAc-2) were first quantitatively sulfated using $\mathrm{SO}_{3} \cdot \mathrm{TMA}(17, \mathrm{cf}$. ii/Scheme 4 and RP HPLC profile b/Scheme 4). The acid-catalyzed benzylidene removal (GalNAc-1) was then carefully optimized, as premature elimination of the sulfonate groups may occur in acidic conditions. An acceptable result was obtained with $0.1 \%$ aqueous TFA ( $5 \mathrm{~h}$ at room temperature, iii/Scheme 4) that removed the benzylidene group (GalNAc-1) and kept the sulfonate groups (GalNAc-2) mainly intact (18, traces of elimination side products observed, $\mathrm{c} /$ Scheme 4$)$. To obtain 21, the exposed 4- and 6-OH groups (GalNAc-2) were first acetylated (19, cf. iv and d/Scheme 4), and then the benzylidene group (GalNAc1) was removed by $80 \%$ aqueous acetic acid to give $20\left(1 \mathrm{~h}\right.$ at $100{ }^{\circ} \mathrm{C}$, cf. $\mathrm{v}$ and e/Scheme 4$)$. It may be worth mentioning that the chloroacetyl groups are too prone to acid-catalyzed hydrolysis, and hence, the acyl replacement (at GalNAc2, 19 vs 16) was required prior to the benzylidene removal (GalNAc1). The exposed 4- and 6$\mathrm{OH}$ groups (GalNAc1) were finally sulfated as above (ii and $\mathrm{f}$ / Scheme 4) to give $\mathbf{2 1}$. To obtain 23, the benzylidene group of 16 (GalNAc-1) was removed (22, g/Scheme 4) and simultaneous sulfation of both GalNAc-1 and GalNAc-2 residues gave 23 (h/Scheme 4). Homogenized chondroitin precursors 18, 21, and 23, bearing the azidopropyl arm and base labile protections $(\mathrm{O}-\mathrm{Bz}, \mathrm{O}-\mathrm{Lev}$, and $\mathrm{N}$-trichloroacetyl 
Scheme 5. Synthesis of Carboxyrhodamine-Labeled CSs $(24-26,29,30)^{a}$

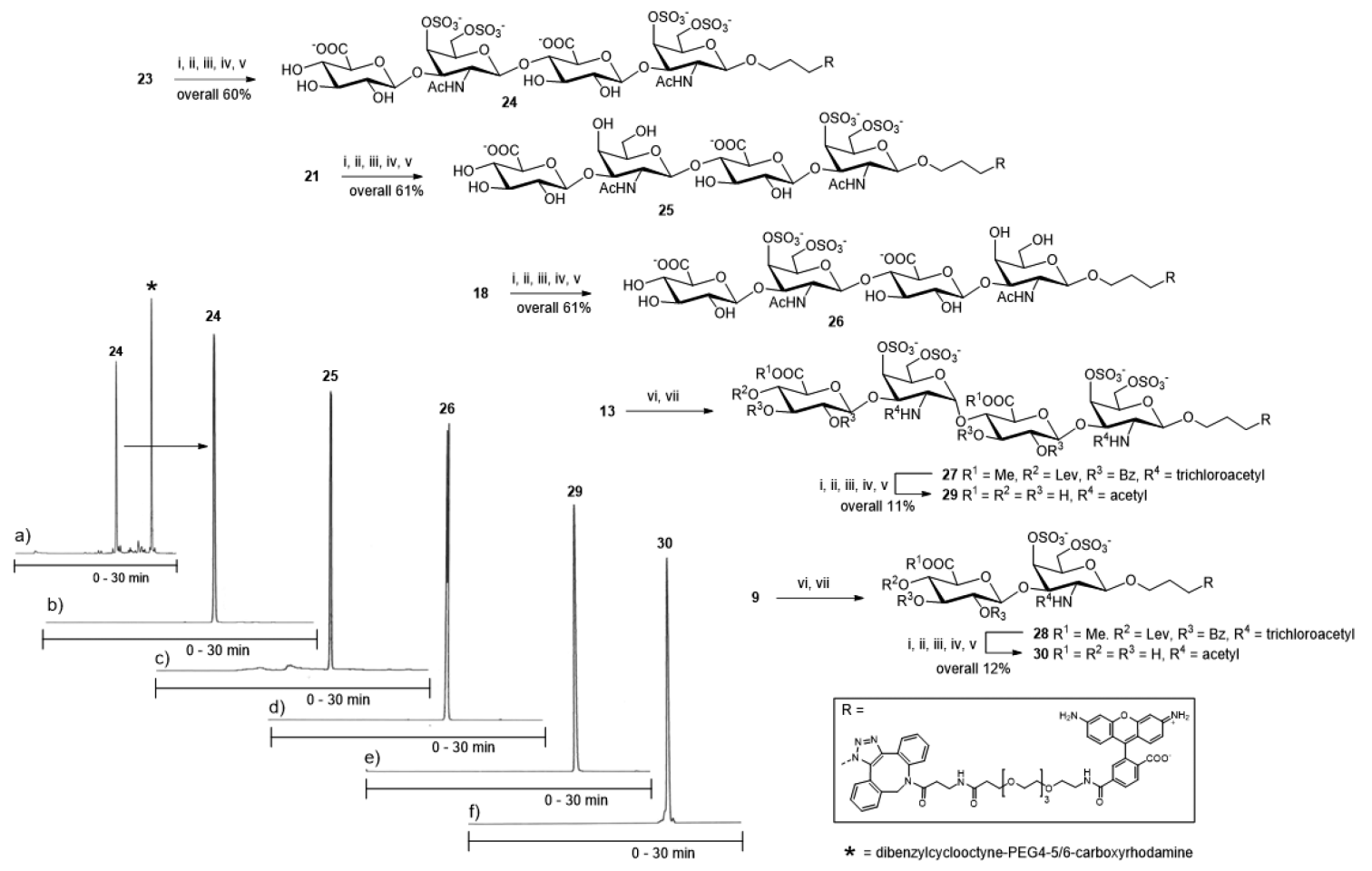

${ }^{a}$ Reagents and conditions: (i) $0.1 \mathrm{~mol} \mathrm{~L}^{-1}$ aq NaOH, $3 \mathrm{~h}$ at $55^{\circ} \mathrm{C}$; (ii) conc. aq $\mathrm{NH}_{3}, 4$ days at $55^{\circ} \mathrm{C}$; (iii) $\mathrm{Ac}_{2} \mathrm{O}, \mathrm{Et}_{3} \mathrm{~N}$, aq $\mathrm{MeCN}$; (iv) conc. aq $\mathrm{NH}_{3}$, $5 \mathrm{~h}$ at $55^{\circ} \mathrm{C}$; (v) dibenzylcyclooctyne-PEG4-5/6-carboxyrhodamine (2 equiv), DMF, overnight at room temperature; (vi) $80 \%$ aq AcOH, $1 \mathrm{~h}$ at $100^{\circ} \mathrm{C}$; (vii) $\mathrm{SO}_{3} \cdot \mathrm{TMA}, \mathrm{DMF}$, overnight at $50^{\circ} \mathrm{C}$. RP HPLC conditions: an analytical RP HPLC column $(250 \times 4.6 \mathrm{~mm}, 5 \mu \mathrm{m})$, flow rate: $1.0 \mathrm{~mL}$ $\mathrm{min}^{-1}$, detection at $501 \mathrm{~nm}$, a gradient elution from 0 to $100 \% \mathrm{MeCN}$ in $0.1 \mathrm{~mol} \mathrm{~L}-1$ aqueous triethyammonium acetate over $30 \mathrm{~min}$. Notes: (a) An

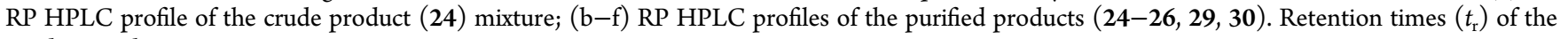
product peaks: 24: $18.8 \mathrm{~min}, 25: 19.3 \mathrm{~min}, 26: 19.4 \mathrm{~min}, 29: 22.0 \mathrm{~min}, 30: 21.8 \mathrm{~min}$.

groups and methyl esters), were finally obtained. Overall isolated yields of $\mathbf{1 8}, \mathbf{2 1}$, and 23 in this $6 \mu \mathrm{mol}$ scale synthesis were 16,21 , and $23 \%$, respectively (calculated from 16 ).

Global Deprotection, $\mathrm{N}$-Acetylation, and Labeling of the CSs. Quantitative global deprotection of 18, 21, and 23 (protected by $\mathrm{O}-\mathrm{Bz}, \mathrm{O}$-Lev, and $\mathrm{N}$-trichloroacetyl groups and methyl esters) was required prior to the labeling or conjugation steps (Schemes 5 and 6). Aqueous sodium hydroxide ( $3 \mathrm{~h}$ at 55 ${ }^{\circ} \mathrm{C}$ ) was used for the hydrolysis of methyl esters of the GlcA residues and of the ester protections ( $\mathrm{O}-\mathrm{Bz}$ and $\mathrm{O}-\mathrm{Lev}$ ) (i/ Scheme 5). The remained $N$-trichloroacetyl groups were then removed by concentrated ammonia ( 4 days at $55^{\circ} \mathrm{C}$, ii/Scheme 5 ). An aliquot of the crude product mixtures was labeled as below, and the completion of the global deprotection was verified by LC-MS analysis (data not shown). The exposed amino groups were then acetylated with a mixture of acetic anhydride and triethylamine in aqueous acetonitrile (iii/ Scheme 5), the plausible $O$-acetyl groups were removed by concentrated ammonia (iv/Scheme 5), and then all CS structures were exposed to SPAAC with dibenzylcyclooctynePEG4-5/6-carboxyrhodamine to give labeled CSs 24-26 (v/ Scheme 5). The global deprotection, $\mathrm{N}$-acetylation and labeling were carried out using $0.3 \mu \mathrm{mol}$ of the CS precursors $(\mathbf{1 8}, \mathbf{2 1}$, or 23) and $0.6 \mu \mathrm{mol}$ ( 2 equiv) of the label. As seen in the example of RP profiles of the crude product mixtures (a/ Scheme 5), the transformation from 18, 21, and 23 to 24-26 could be successfully carried out. Overall isolated yield in each case was ca. 60\%. The labeled CS tetrasaccharide 29 and CS disaccharide 30 were synthesized from 9 and 13 using exactly the same procedures: The benzylidene protections were removed and the exposed hydroxyl groups were sulfated as described to 23 from 16 above. The obtained CS precursors $(\mathbf{2 7}, \mathbf{2 8})$ were purified by RP HPLC and then the transformation, including global deprotection, $\mathrm{N}$-acetylation and labeling with the carboxyrhodamine dye, was carried out. Overall isolated yields of 29 and 30 (calculated from 9 and 13) were 11 and $12 \%$, respectively. The authenticity of 24-26, 29, and 30 was verified MS (ESI-TOF) spectroscopy (cf. Table 1 and the Supporting Information).

SPAAC Conjugation with a Cyclooctyne-Modified Oligonucleotide. DNA-directed immobilization (DDI) of carbohydrates may be used to provide high throughput tools to study protein carbohydrate interactions on a DNA-based micro array. ${ }^{42}$ The carbohydrates are usually conjugated to the $5^{\prime}$ end of appropriate DNA sequences and immobilized then via hybridization with the complementary strands at a specific location of the array. ${ }^{42}$ For the preparation of the carbohydrateoligonucleotide conjugates, a straightforward and high yielding procedure is needed. As the global deprotection/ $\mathrm{N}$-acylation step above proved virtually quantitative (cf. RP HPLC analysis of crude product mixture of $\mathbf{2 4}$, a/Scheme 5), the applicability of the azidopropyl modified CS precursors (18, 21, and 23, Scheme 4) was evaluated to gain 5'-CS-oligonucleotide conjugates (32-34, Scheme 6). 18, 21, and 23 (20 nmol) were exposed to the global deprotection and $N$-acetylated as above and treated then with a $5^{\prime}$-cyclooctyne modified $2{ }^{\prime}$-deoxy oligoribonucleotide (31, the same sequence previously used for DDI on a carbohydrate microarray ${ }^{42}$ ). The reactions were 
Scheme 6. Synthesis of CS-Oligonucleotide Conjugates $(32-34)^{a}$
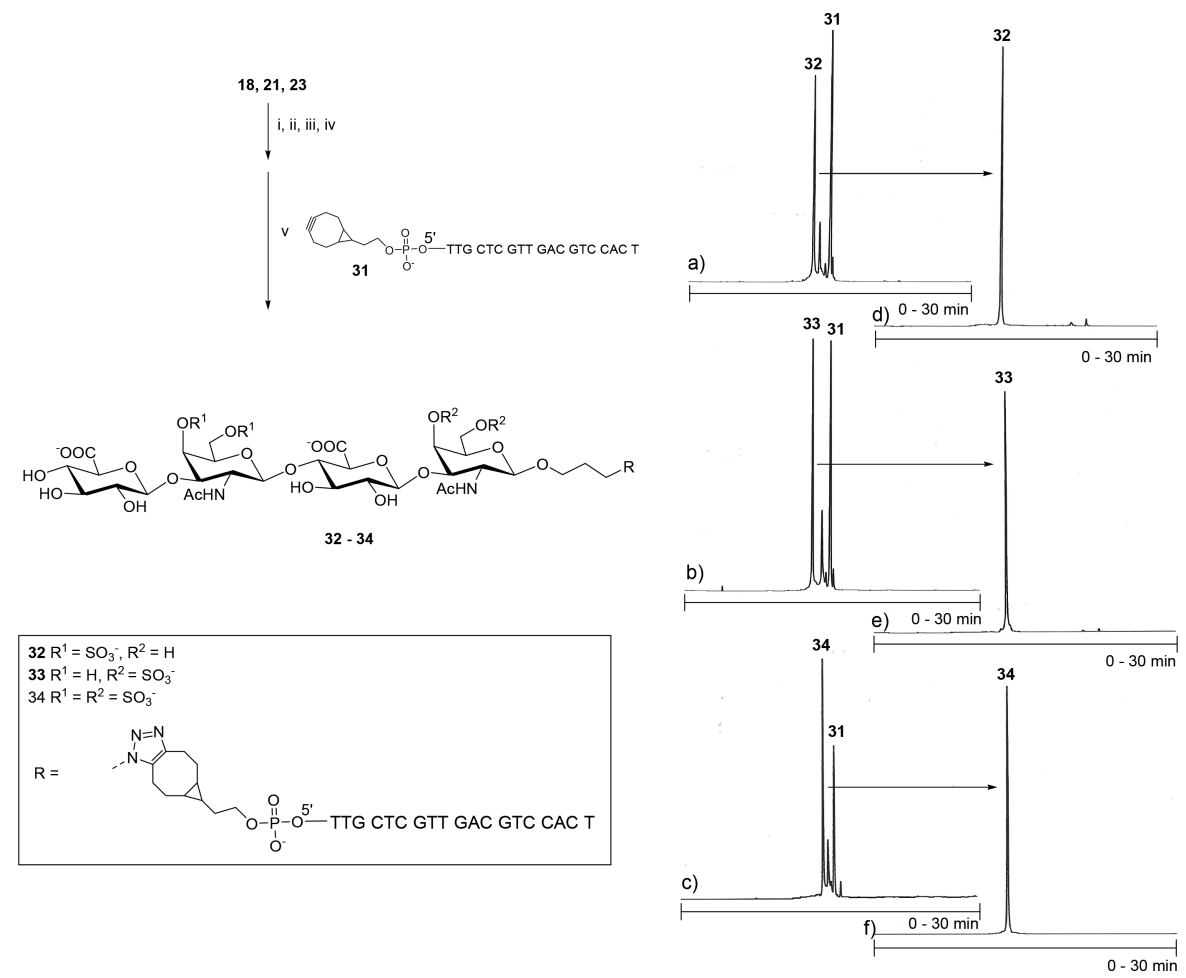

${ }^{a}$ Reagents and conditions: (i) $0.1 \mathrm{~mol} \mathrm{~L}{ }^{-1}$ aq NaOH, 3 h at $55^{\circ} \mathrm{C}$; (ii) conc. aq $\mathrm{NH}_{3}, 4$ days at $55^{\circ} \mathrm{C}$; (iii) $\mathrm{Ac}_{2} \mathrm{O}, \mathrm{Et}_{3} \mathrm{~N}$, aq $\mathrm{MeCN}$; (iv) conc. aq $\mathrm{NH}_{3}$, $5 \mathrm{~h}$ at $55^{\circ} \mathrm{C}$; (v) $5^{\prime}$-cyclooctyne-modified $2^{\prime}$-deoxy oligoribonucleotide 31 (1.5 equiv), $\mathrm{H}_{2} \mathrm{O}$, overnight at $55^{\circ} \mathrm{C}$.; RP HPLC conditions: an analytical RP HPLC column $(250 \times 4.6 \mathrm{~mm}, 5 \mu \mathrm{m})$, flow rate: $1.0 \mathrm{~mL} \mathrm{~min}^{-1}$, detection at $260 \mathrm{~nm}$, a gradient elution from 0 to $70 \% \mathrm{MeCN}$ in $0.1 \mathrm{~mol} \mathrm{~L}-1$ aqueous triethylammonium acetate over $30 \mathrm{~min}$. An RP HPLC profile of the crude $(\mathrm{a}-\mathrm{c})$ and homogenized $(\mathrm{d}-\mathrm{f})$ products $\left(32: t_{\mathrm{r}}=13.4 \mathrm{~min}, 33: t_{\mathrm{r}}\right.$ $\left.=13.0 \mathrm{~min}, 34: t_{\mathrm{r}}=13.2 \mathrm{~min}\right)$.

Table 1. MS(ESI-TOF) Data of the Labeled CSs $\left(24-26,29,30:[(\mathrm{M}-2 \mathrm{H}) / 2]^{2-}\right)$ and CS-Oligonucleotide Conjugates $(32-34$ : $\left.[(\mathbf{M}-\mathbf{4 H}) / 4]^{4-}\right)$

\begin{tabular}{|cccccccccc}
\hline labeled CSs & $\mathbf{2 4}$ & $\mathbf{2 5}$ & $\mathbf{2 6}$ & $\mathbf{2 9}$ & $\mathbf{3 0}$ & $\mathbf{3 2}$ & $\mathbf{3 3}$ & $\mathbf{3 4}$ \\
\hline observed molecular mass & 1028.32 & 948.36 & 948.37 & 1028.23 & 758.70 & 1746.8 & 1746.8 & 1786.8 \\
calculated molecular mass & 1028.22 & 948.26 & 948.27 & 1028.22 & 758.71 & 1747.0 & 1747.0 & 1787.0
\end{tabular}

performed using an excess of the oligonucleotide (1.5 equiv, 1 mmol $\mathrm{L}^{-1}$ solution in water, overnight at $\left.55^{\circ} \mathrm{C}\right)$, and the completion of the reactions was verified by an RP-HPLC analysis (Scheme 6). In each case, the crude product mixture contained the remained excess of the oligonucleotide (31), but the desired CS-glycoconjugate $(32,33$, and 34 , conversion yield according to peak areas: 70,75 , and $90 \%$, respectively) could be readily homogenized. The authenticity of the products was verified by MS(ESI-TOF) spectroscopy (cf. Table 1 and the Supporting Information).

HP Neuron Cell Imaging with the Labeled CS Tetrasaccharide 29 and Disaccharide 30. In the nervous system, CS bound to core protein forms CS proteoglycan (CSPG), a major component of the brain extracellular matrix. It functions as a regulator of plasticity and axon guidance during brain development and inhibits regeneration in the adult central nervous system. ${ }^{43}$ Interestingly, CSPG has been found to bind to receptors raising the possibility that CS conjugates may be taken up into neuronal cells. To test this and to demonstrate that even CS structures with a nonregular $\alpha$-glycosidic bond may show activity, preliminary cellular uptake studies with 29 were carried out. Hippocampal neurons were incubated with labeled disaccharide 30 (modest affinity control) and tetrasaccharide 29 at $50 \mathrm{nM}$ for 10 days, after which confocal imaging through nuclei was carried out to determine whether uptake had occurred. At this concentration, 29 was visible as bright puncta in the cytosol that resembled endosomes surrounding the nucleus and in the neurites (Figure 1). This distribution pattern is consistent with receptor-mediated uptake. A distinctly different pattern was obtained when the carboxyrhodamine dye alone was used. This was likely internalized via phagocytosis. When used at a higher concentration ( 200 to $500 \mathrm{nM}$ ), 29 uptake was observed in more than $80 \%$ of neurons and the signal was detectable even in the distal neurites. Uptake of $\mathbf{2 9}$ was not observed in neurons that were older than 15 days in vitro. The labeled disaccharide 30 was not taken up at all by hippocampal neurons at any of the tested concentrations $(50-500 \mathrm{nM})$. These results suggest that 29 may be specifically taken up via receptor-mediated endocytosis in neurons, whereas $\mathbf{3 0}$ is not.

\section{CONCLUSIONS}

In this primarily synthetic description, azidopropyl-modified precursors of CS tetrasaccharides have been prepared, which, after facile conversion to final CS structures (i.e., global deprotection and $N$-acetylation: (1) $0.1 \mathrm{~mol} \mathrm{~L}^{-1}$ aq NaOH, $3 \mathrm{~h}$ 


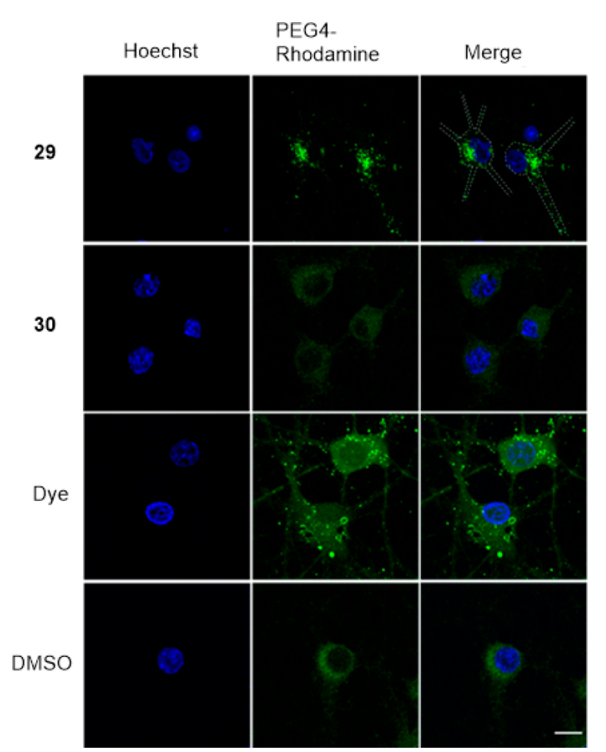

Figure 1. Labeled CSs (29 and 30) images. Cultured hippocampal neurons from rat brain at 7 days in vitro were treated with $\mathrm{CS}$ conjugates $(29$ or 30$)$ at 50 or $10 \mathrm{nM}$ unconjugated dye (DBCOPEG4-5/6-Carboxyrhodamine 110) or with DMSO for 10 days as indicated. Cells were fixed with $4 \%$ cold paraformaldehyde in phosphate buffered saline and stained with Hoechst-33342. Confocal images of Z-sections through nuclei are shown. Signal for the conjugates or the dye is shown in green while nuclei are highlighted in blue. Scale $=10 \mu \mathrm{m}$.

at $55{ }^{\circ} \mathrm{C}$; (2) conc. aq $\mathrm{NH}_{3}, 4$ days at $55{ }^{\circ} \mathrm{C}$; (3) $\mathrm{Ac}_{2} \mathrm{O}, \mathrm{Et}_{3} \mathrm{~N}$, aq $\mathrm{MeCN}$ ) may be conjugated with alkyne-modified target compounds by a one-pot "click"-ligation. RP HPLC was used for the monitoring of the key reaction steps (protecting group manipulation and sulfation) and purification of the CS precursors. The global deprotection $/ \mathrm{N}$-acetylation of the precursors proved to be virtually quantitative converting the precursors to final CS structures, which were then exposed to SPAAC conjugation with dibenzylcyclooctyn-modified carboxyrhodamine dye and a cyclooctyne modified oligonucleotide to give labeled CSs (24-26 and 29) and CS-oligonucleotide conjugates (32-34), respectively. While most of the synthetic procedures of CSs requires specialized expertise in carbohydrate chemistry, the present miniature procedure of the precursors has been designed to be more readily accessible by multidisciplinary bioorganic research groups offering new tools for biologists. Particularly our approach provides robust analytical method for protecting group manipulations of different sulfation patterns using HPLC and MS (ESI-TOF). Moreover, an azide group (not an alkyne) was introduced to the precursors, which may be more straightforward choice for the synthesis biomolecular hybrids via SPAAC (as demonstrated by $32-34$ ). To demonstrate the potential neuronal activity of the labeled CSs, preliminary cellular uptake studies with hippocampal neurons and 29 vs 30 were demonstrated. More detailed affinity studies and applications of the CSprecursors are currently underway in our laboratory. The preparation of 5'-CS-oligonucleotides proved efficient, which may, via DDI, be expanded to protein-CS interaction studies on a DNA-based micro array. Moreover, conjugated CSs may find applications as a novel targeted delivery strategy for therapeutic oligonucleotides, which should be studied in more detail.

\section{EXPERIMENTAL PROCEDURES}

General Remarks. $\mathrm{CH}_{2} \mathrm{Cl}_{2}, \mathrm{DMF}$, toluene, pyridine, and methanol were dried over molecular sieves. Solid reagents were dried over $\mathrm{P}_{2} \mathrm{O}_{5}$ in a vacuum desiccator. The NMR spectra were recorded at 400 or $500 \mathrm{MHz}$. Chemical shifts are given in ppm using internal TMS or solvent residual signals as reference. Appropriate 1D and 2D NMR methods (e.g., TOCSY, COSY, DEPT, and HSQC) were used for peak assignment. The mass spectra were recorded using a MS (ESI-TOF) spectrometer. RP HPLC analysis and purification of the oligosaccharides were performed using a Thermo ODS Hypersil C18 $(150 \times 4.6 \mathrm{~mm}$, $5 \mu \mathrm{m})$ analytical column. The correct yields of 18, 21, and 23 (i.e., amounts of the RP HPLC isolated products synthesized using $5.9 \mu \mathrm{mol} 16$ as a starting material) were determined by comparing the intensity of the ${ }^{1} \mathrm{H}$ NMR signals to a known amount of acetonitrile.

tert-Butyldimethylsilyl 3,4,6-Tri-O-acetyl-2-deoxy-2-trichloroacetamido- $\beta$-D-galactopyranoside (2). Compound 1 $(6.1 \mathrm{~g}, 12 \mathrm{mmol})$ was dissolved in DMF $(100 \mathrm{~mL})$ and hydrazine acetate $(1.7 \mathrm{~g}, 19 \mathrm{mmol})$ was added. The reaction mixture was stirred for $3 \mathrm{~h}$ at ambient temperature, diluted with EtOAc and washed with saturated aqueous $\mathrm{NaHCO}_{3}$ and brine. The combined organic layers were dried over $\mathrm{Na}_{2} \mathrm{SO}_{4}$, filtered, and evaporated to dryness. Purification by silica gel column chromatography (20\% EtOAc in petroleum ether) gave compound 2 (4.8 g, 86\%) as a white solid. ${ }^{1} \mathrm{H}$ NMR (400 $\left.\mathrm{MHz}, \mathrm{CDCl}_{3}\right): \delta 0.11(\mathrm{~s}, 3 \mathrm{H}), 0.14(\mathrm{~s}, 3 \mathrm{H}), 0.89$ (s, 9H), 1.99 $(\mathrm{s}, 3 \mathrm{H}), 2.01(\mathrm{~s}, 3 \mathrm{H}), 2.18(\mathrm{~s}, 3 \mathrm{H}), 3.94(\mathrm{~m}, 1 \mathrm{H}), 4.06-4.20$ $(\mathrm{m}, 3 \mathrm{H}), 4.91(\mathrm{~d}, J=7.9 \mathrm{~Hz}), 5.28(\mathrm{dd}, 1 \mathrm{H}, J=3.4$ and 11.3 $\mathrm{Hz}), 5.38(\mathrm{dd}, 1 \mathrm{H}, J=0.6$ and $3.2 \mathrm{~Hz}), 6.72(\mathrm{~d}, 1 \mathrm{H}, J=8.9$ $\mathrm{Hz}) ;{ }^{13} \mathrm{C}\left(100 \mathrm{MHz}, \mathrm{CDCl}_{3}\right) \delta-5.1,-4.2,17.8,20.5,20.6$, 20.7, 25.5, 55.0, 61.7, 66.8, 69.4, 71.0, 92.4, 96.0, 161.8, 170.2, 170.4; HRMS (ESI-TOF): $m / z$ calcd for $\mathrm{C}_{20} \mathrm{H}_{31} \mathrm{Cl}_{3} \mathrm{NO}_{9} \mathrm{Si}$ $562.0834[\mathrm{M}-\mathrm{H}]^{-}$, found 562.0814 .

1-tert-Butyldimethylsilyl 4,6-O-Benzylidene-2-deoxy-2-trichloroacetamido- $\beta$-D-galactopyranoside (3). 2 (6.2 g, 11 $\mathrm{mmol}$ ) was dissolved in a mixture of $0.1 \mathrm{~mol} \mathrm{~L}^{-1} \mathrm{NaOMe}$ in $\mathrm{MeOH}(20 \mathrm{~mL})$. The reaction mixture was stirred at room temperature for $3 \mathrm{~h}$, neutralized by addition of strong cation exchange resin, filtered, and evaporated to dryness. The residue $(4.1 \mathrm{~g})$ was dissolved in acetonitrile $(55 \mathrm{~mL})$, benzaldehyde dimethylacetal $(3.8 \mathrm{~mL}, 25 \mathrm{mmol})$ and $p$-TSA (45 mg, 0.23 $\mathrm{mmol}$ ) were added and the reaction mixture was stirred overnight at ambient temperature. The mixture was neutralized by addition of saturated aqueous $\mathrm{NaHCO}_{3}$ and the product was extracted with $\mathrm{CH}_{2} \mathrm{Cl}_{2}$. The organic layers were combined, washed with brine, dried over $\mathrm{Na}_{2} \mathrm{SO}_{4}$, filtered, and evaporated to dryness. Purification by silica gel chromatography (40\% EtOAc in petroleum ether) yielded $3(4.7 \mathrm{~g}, 82 \%)$ as a white solid. ${ }^{1} \mathrm{H}$ NMR (500 MHz, $\left.\mathrm{CDCl}_{3}\right): \delta 0.14(\mathrm{~s}, 3 \mathrm{H}), 0.18$ (s, $3 \mathrm{H}), 0.90(\mathrm{~s}, 9 \mathrm{H}), 3.50(\mathrm{~d}, 1 \mathrm{H}, J=1.2), 3.83(\mathrm{~m}, 1 \mathrm{H}), 4.05-$ $4.09(\mathrm{~m}, 2 \mathrm{H}), 4.21(\mathrm{dd}, 1 \mathrm{H}, J=3.6$ and $0.6 \mathrm{~Hz}), 4.27(\mathrm{dd}, 1 \mathrm{H}, J$ $=12.3$ and $1.4 \mathrm{~Hz}), 4.95(\mathrm{~d}, 1 \mathrm{H}, J=7.9 \mathrm{~Hz}), 5.56(\mathrm{~s}, 1 \mathrm{H}), 6.84$ $(\mathrm{d}, 1 \mathrm{H}, J=7.7 \mathrm{~Hz}), 7.36-7.38(\mathrm{~m}, 3 \mathrm{H}), 7.50-7.52(\mathrm{~m}, 2 \mathrm{H})$; ${ }^{13} \mathrm{C}\left(125 \mathrm{MHz}, \mathrm{CDCl}_{3}\right): \delta-4.7,-3.9,18.0,25.7,58.5,66.7$, 69.2, 69.6, 75.0, 92.5, 95.2, 101.4, 126.4, 128.3, 129.3, 137.5, 162.4; HRMS (ESI-TOF): $m / z$ calcd for $\mathrm{C}_{21} \mathrm{H}_{29} \mathrm{Cl}_{3} \mathrm{NO}_{6} \mathrm{Si}$ $524.0808[\mathrm{M}-\mathrm{H}]^{-}$, found 524.0827 .

tert-Butyldimethylsilyl 4,6-O-Benzylidene-2-deoxy-3-O-levulinoyl-2-trichloroacetamido- $\beta$-D-galactopyranoside (4). A mixture of levulinic acid $(2.0 \mathrm{~g}, 17 \mathrm{mmol})$ and DCC $(1.8 \mathrm{~g}$, $8.5 \mathrm{mmol})$ in $\mathrm{CH}_{2} \mathrm{Cl}_{2}(10 \mathrm{~mL})$ and a catalytic amount of 
DMAP were added to a solution of $3(1.8 \mathrm{~g}, 3.4 \mathrm{mmol})$ in $\mathrm{CH}_{2} \mathrm{Cl}_{2}(10 \mathrm{~mL})$. The reaction mixture was stirred overnight at ambient temperature, filtered, and concentrated, and the residue was partitioned between EtOAc and water. The organic layer was separated, washed with saturated aqueous $\mathrm{NaHCO}_{3}$, dried over $\mathrm{Na}_{2} \mathrm{SO}_{4}$, and evaporated to dryness. Purification by column chromatography (40\% EtOAc in petroleum ether) yielded $4(1.9 \mathrm{~g}, 89 \%)$ as a white solid. ${ }^{1} \mathrm{H}$ NMR (500 MHz, $\left.\mathrm{CDCl}_{3}\right): \delta 0.13(\mathrm{~s}, 3 \mathrm{H}), 0.18(\mathrm{~s}, 3 \mathrm{H}), 0.89(\mathrm{~s}, 9 \mathrm{H}), 2.05$ (s, $3 \mathrm{H}), 2.25-2.75(\mathrm{~m}, 4 \mathrm{H}), 3.53(\mathrm{~d}, 1 \mathrm{H}, J=1.1 \mathrm{~Hz}), 4.07(\mathrm{dd}$, $1 \mathrm{H}, J=12.3$ and $1.8 \mathrm{~Hz}$ ), $4.17(\mathrm{ddd}, 1 \mathrm{H}, J=11.3 \mathrm{~Hz}, 8.2$ and $8.2 \mathrm{~Hz}$ ), 4.27 (dd, $1 \mathrm{H}, J=1.4$ and $12.3 \mathrm{~Hz}), 4.30(\mathrm{~d}, 1 \mathrm{H}, J=3.2$ $\mathrm{Hz}$ ), $5.03(\mathrm{~d}, 1 \mathrm{H}, J=7.9 \mathrm{~Hz}), 5.28(\mathrm{dd}, 1 \mathrm{H}, J=11.3$ and 3.5 $\mathrm{Hz}), 5.53(\mathrm{~s}, 1 \mathrm{H}), 6.71(\mathrm{~d}, 1 \mathrm{H}, J=8.6 \mathrm{~Hz}), 7.35-7.40(\mathrm{~m}$, $3 \mathrm{H}), 7.52-7.54(\mathrm{~m}, 2 \mathrm{H}) ;{ }^{13} \mathrm{C}\left(125 \mathrm{MHz}, \mathrm{CDCl}_{3}\right) \delta-4.6,-3.9$, 17.9, 25.7, 28.0, 29.7, 37.7, 54.8, 66.4, 69.2, 70.1, 73.1, 92.5, 95.6, 101.0, 126.4, 128.2, 129.1, 137.6, 161.6, 172.4, 206.4; HRMS (ESI-TOF): $m / z$ calcd for $\mathrm{C}_{26} \mathrm{H}_{35} \mathrm{Cl}_{3} \mathrm{NO}_{8} \mathrm{Si} 622.1198$ $[\mathrm{M}-\mathrm{H}]^{-}$, found 622.1204 .

4,6-O-Benzylidene-2-deoxy-3-O-levulinoyl-2-trichloroacetaimido- $\alpha$-D-galactopyranosyl trichloroacetimidate (5). $\mathrm{Et}_{3} \mathrm{~N}$.3HF $(2.1 \mathrm{~mL}, 13 \mathrm{mmol})$ was added to a solution of 4 $(2.0 \mathrm{~g}, 3.1 \mathrm{mmol})$ in THF $(5 \mathrm{~mL})$, and the mixture was stirred overnight at ambient temperature. The mixture was evaporated to dryness and the residue was purified by silica gel chromatography (40\% EtOAc/toluene) to give the desired hemiacetal $(1.4 \mathrm{~g})$ as a white foam. The hemiacetal was dissolved in $\mathrm{CH}_{2} \mathrm{Cl}_{2}(4 \mathrm{~mL})$ and $\mathrm{CCl}_{3} \mathrm{CN}(4 \mathrm{~mL})$, the mixture was cooled to $0{ }^{\circ} \mathrm{C}$, and $\mathrm{DBU}(82 \mu \mathrm{L}, 0.54 \mathrm{mmol})$ was added. The mixture was stirred for $30 \mathrm{~min}$ at $0{ }^{\circ} \mathrm{C}$, evaporated to dryness and purified by silica gel chromatography (40\% EtOAc in toluene) to yield $5(2.1 \mathrm{~g}, 78 \%$ after two steps $)$ as a white foam. ${ }^{1} \mathrm{H}$ NMR (500 MHz, $\mathrm{CDCl}_{3}$ ): $\delta 2.10(\mathrm{~s}, 3 \mathrm{H}), 2.57-2.75$ $(\mathrm{m}, 4 \mathrm{H}), 3.96(\mathrm{~d}, 1 \mathrm{H}, J=0.4 \mathrm{~Hz}), 4.08(\mathrm{dd}, 1 \mathrm{H}, J=12.7$ and $1.5 \mathrm{~Hz}$ ), 4.35 (dd, $1 \mathrm{H}, J=12.7$ and $1.5 \mathrm{~Hz}), 4.45(\mathrm{~d}, 1 \mathrm{H}, J=2.7$ $\mathrm{Hz}), 4.88(\mathrm{~m}, 1 \mathrm{H}), 5.46(\mathrm{dd}, 1 \mathrm{H}, J=11.3$ and $3.2 \mathrm{~Hz}), 5.59(\mathrm{~s}$, $1 \mathrm{H}), 6.63(\mathrm{~d}, 1 \mathrm{H}, J=3.3 \mathrm{~Hz}), 6.96(\mathrm{~d}, 1 \mathrm{H}, J=8.6 \mathrm{~Hz}), 7.37-$ $7.42(\mathrm{~m}, 3 \mathrm{H}), 7.53-7.55(\mathrm{~m}, 2 \mathrm{H}), 8.78(\mathrm{~s}, 1 \mathrm{H}) ;{ }^{13} \mathrm{C}(125$ $\left.\mathrm{MHz}, \mathrm{CDCl}_{3}\right): \delta 28.1,29.7,37.7,49.8,65.2,68.4,68.8,73.1$, $90.8,92.0,95.3,101.0,126.3,128.3,129.2,137.2,160.1,162.0$, 173.4, 206.3; HRMS (ESI-TOF): $\mathrm{m} / z$ calcd for $\mathrm{C}_{22} \mathrm{H}_{22} \mathrm{Cl}_{6} \mathrm{~N}_{2} \mathrm{NaO}_{6} 674.9405[\mathrm{M}+\mathrm{Na}]^{+}$, found 674.9391 .

3-Azidopropyl (4,6-Benzylidene-2-deoxy-3-O-levulinoyl-2trichloroacetaimido- $\beta$-D-galactopyranoside) (6). Azidopropanol (0.74 mg, $7.3 \mathrm{mmol}$ ) and 5 (1.6 g, $2.4 \mathrm{mmol})$ were combined and dried by repeated coevaporation with toluene. The dried residue was dissolved in dry $\mathrm{CH}_{2} \mathrm{Cl}_{2}(10 \mathrm{~mL}), 4 \AA$ MS were added, and the mixture stirred at room temperature under nitrogen for $30 \mathrm{~min}$. The mixture was cooled to $-30^{\circ} \mathrm{C}$, TMSOTf $(35.5 \mu \mathrm{L}, 0.19 \mathrm{mmol})$ was added, and the mixture was stirred for $45 \mathrm{~min}$ under nitrogen. The mixture was neutralized by addition of triethylamine, filtered, evaporated to dryness, and purified by column chromatography (25\% EtOAc in petroleum ether) to yield $6(0.79 \mathrm{~g}, 55 \%)$ as a white solid. ${ }^{1} \mathrm{H}$ NMR (500 MHz, $\left.\mathrm{CDCl}_{3}\right): \delta 1.80-1.92(\mathrm{~m}, 1 \mathrm{H}), 2.99(\mathrm{~s}, 3 \mathrm{H})$, 2.56-2.75 (m, 4H), $3.39(\mathrm{~m}, 1 \mathrm{H}), 3.57(\mathrm{~d}, 1 \mathrm{H}, J=1.0 \mathrm{~Hz})$, $3.60(\mathrm{~m}, 1 \mathrm{H}), 4.03(\mathrm{~m}, 1 \mathrm{H}), 4.09(\mathrm{dd}, 1 \mathrm{H}, J=12.4$ and 1.7 $\mathrm{Hz}), 4.21(\mathrm{~m}, 1 \mathrm{H}), 4.31-4.36(\mathrm{~m}, 2 \mathrm{H}), 4.83(\mathrm{~d}, 1 \mathrm{H}, J=8.3$ $\mathrm{Hz}), 5.34(\mathrm{dd}, 1 \mathrm{H}, J=11.3$ and $3.5 \mathrm{~Hz}), 5.55(\mathrm{~s}, 1 \mathrm{H}), 6.84(\mathrm{~d}$, $1 \mathrm{H}, J=8.3 \mathrm{~Hz}), 7.35-7.40(\mathrm{~m}, 3 \mathrm{H}), 7.52-7.54(\mathrm{~m}, 2 \mathrm{H}) ;{ }^{13} \mathrm{C}$ $\left(125 \mathrm{MHz}, \mathrm{CDCl}_{3}\right): \delta 28.1,29.0,29.7,37.8,48.1,52.9,66.1$, $66.5,69.0,70.0,73.1,92.4,100.2,100.9,126.3,128.2,129.1$,
137.4, 162.0, 172.4, 206.5; HRMS (ESI-TOF): $\mathrm{m} / z$ calcd for $\mathrm{C}_{23} \mathrm{H}_{26} \mathrm{Cl}_{3} \mathrm{~N}_{4} \mathrm{O}_{8} 591.0816[\mathrm{M}-\mathrm{H}]^{-}$, found 591.0863.

3-Azidopropyl (4,6-Benzylidene-2-deoxy-trichloroacetamido- $\beta$-D-galactopyranoside) (7). 6 (0.77 g, $1.3 \mathrm{mmol})$ was dissolved in a mixture of hydrazine hydrate $(6.5 \mathrm{mmol}), \mathrm{AcOH}$, and pyridine $\left(\mathrm{NH}_{2} \mathrm{NH}_{2} \cdot \mathrm{H}_{2} \mathrm{O}, \mathrm{AcOH}\right.$, pyridine, 0.124:1:4, v/v/ $\mathrm{v})$. The reaction mixture was stirred for $15 \mathrm{~min}$ at ambient temperature, diluted with EtOAc, and washed with $1.0 \mathrm{~mol} \mathrm{~L}^{-1}$ $\mathrm{HCl}$ aq, aqueous $\mathrm{NaHCO}_{3}$, and brine. The organic layer was dried over $\mathrm{Na}_{2} \mathrm{SO}_{4}$ and concentrated in vacuo. Purification by silica gel chromatography ( $40 \%$ EtOAc in petroleum ether) yielded 7 as a white solid $(0.51 \mathrm{~g}, 77 \%) .{ }^{1} \mathrm{H}$ NMR $(500 \mathrm{MHz}$, $\left.\mathrm{CDCl}_{3}\right): \delta 1.80-1.92(\mathrm{~m}, 2 \mathrm{H}), 3.40(\mathrm{~m}, 2 \mathrm{H}), 3.54(\mathrm{~d}, 1 \mathrm{H}, J=$ $1.1 \mathrm{~Hz}), 3.58(\mathrm{~m}, 1 \mathrm{H}), 3.87(\mathrm{~m}, 1 \mathrm{H}), 4.01(\mathrm{~m}, 1 \mathrm{H}), 4.06(\mathrm{~m}$, $1 \mathrm{H}), 4.10$ (dd, $1 \mathrm{H}, J=12.5 \mathrm{~Hz}, 1.8 \mathrm{~Hz}, \mathrm{H}-6), 4.23(\mathrm{~b}, 1 \mathrm{H})$, $4.34(\mathrm{dd}, 2 \mathrm{H}, J=12.5$ and $1.4 \mathrm{~Hz}), 4.75(\mathrm{dd}, 1 \mathrm{H}, J=2.0$ and $8.3 \mathrm{~Hz}$ ), $5.58(\mathrm{~s}, 1 \mathrm{H}), 7.34-7.40(\mathrm{~m}, 3 \mathrm{H}), 7.52-7.54(\mathrm{~m}, 2 \mathrm{H})$; ${ }^{13} \mathrm{C}\left(125 \mathrm{MHz}, \mathrm{CDCl}_{3}\right): \delta 29.0,48.1,55.9,66.2,66.7,69.1$, 69.3, 75.2, 92.6, 100.0, 101.3, 126.4, 128.3, 129.4, 137.3, 162.7; HRMS (ESI-TOF): $m / z$ calcd for $\mathrm{C}_{18} \mathrm{H}_{21} \mathrm{Cl}_{3} \mathrm{~N}_{4} \mathrm{NaO}_{6} 517.0424$ $[\mathrm{M}+\mathrm{Na}]^{+}$, found 517.0411 .

3-Azidopropyl (Methyl 2,3-di-O-benzoyl-4-O-levulinoyl- $\beta$ D-glucopyranosyluronate)-(1 $\rightarrow$ 3)-(4,6-O-benzylidene-2deoxy-2-trichloroacetamido- $\beta$-D-glucopyranoside) (9). (Methyl 2,3-di-O-benzoyl-4-O-levulinoyl-D-glucopyranosyluronate) trichloroacetimidate $(8,32 \mathrm{~g}, 0.48 \mathrm{mmol})^{39}$ and 7 (191 $\mathrm{mg}, 0.38 \mathrm{mmol}$ ) were dried by repeated coevaporation with toluene and dissolved in dry $\mathrm{CH}_{2} \mathrm{Cl}_{2}(3 \mathrm{~mL}) .4 \AA \mathrm{MS}$ were added, and the mixture was stirred at room temperature under nitrogen for $30 \mathrm{~min}$. The reaction mixture was cooled to $0{ }^{\circ} \mathrm{C}$, TMSOTf $(7.0 \mu \mathrm{L}, 0.03 \mathrm{mmol})$ was added, and the mixture was stirred for $1 \mathrm{~h}$ under nitrogen. The mixture was neutralized by addition of triethylamine, filtered, evaporated to dryness, and purified by silica gel column chromatography (45\% EtOAc in toluene) to give $9(0.25 \mathrm{~g}, 66 \%)$ as a white solid. ${ }^{1} \mathrm{H}$ NMR (400 $\mathrm{MHz}_{\mathrm{CDCl}}$ ): $\delta$ 1.77-1.85 (m, 2H), $2.04(\mathrm{~s}, 3 \mathrm{H}), 2.35-2.63$ $(\mathrm{m}, 4 \mathrm{H}), 3.34(\mathrm{~m}, 2 \mathrm{H}), 3.51(\mathrm{~b}, 1 \mathrm{H}), 3.56(\mathrm{~m}, 1 \mathrm{H}), 3.74(\mathrm{~m}$, $1 \mathrm{H}), 3.77(\mathrm{~s}, 3 \mathrm{H}), 3.96(\mathrm{~m}, 1 \mathrm{H}), 4.08(\mathrm{dd}, 1 \mathrm{H}, J=12.5$ and 1.5 $\mathrm{Hz}), 4.21(\mathrm{~d}, 1 \mathrm{H}, J=9.9 \mathrm{~Hz}), 4.32(\mathrm{dd}, 1 \mathrm{H}, J=12.4$ and 1.3 $\mathrm{Hz}), 4.47(\mathrm{~d}, 1 \mathrm{H}, J=4.2 \mathrm{~Hz}), 4.70(\mathrm{dd}, 1 \mathrm{H}, J=11.2$ and 3.5 $\mathrm{Hz}$ ), 5.06 (d, $1 \mathrm{H}, J=8.2 \mathrm{~Hz}), 5.21(\mathrm{~d}, 1 \mathrm{H}, J=7.4 \mathrm{~Hz}), 5.44-$ $5.52(\mathrm{~m}, 2 \mathrm{H}), 5.54(\mathrm{~s}, 1 \mathrm{H}), 5.65(\mathrm{dd}, 1 \mathrm{H}, J=9.1$ and $9.1 \mathrm{~Hz})$, $7.00(\mathrm{~d}, 1 \mathrm{H}, J=6.7 \mathrm{~Hz}), 7.31-7.39(\mathrm{~m}, 7 \mathrm{H}), 7.47-7.52(\mathrm{~m}, 4$ $\mathrm{H}), 7.85-7.89(\mathrm{~m}, 4 \mathrm{H}) ;{ }^{13} \mathrm{C}\left(100 \mathrm{MHz}, \mathrm{CDCl}_{3}\right) \delta 27.7,29.0$, 29.6, 37.5, 48.2, 53.1, 55.2, 66.5, 66.7, 69.0, 69.4, 71.4, 72.2, $72.5,73.5,75.7,92.2,98.7,100.1,100.6,126.1,128.1,128.2$, $128.4,128.7,128.8,129.9,129.0,133.4,137.7,162.2,164.9$, 165.5, 167.2, 171.2, 205.6; HRMS (ESI-TOF): $\mathrm{m} / \mathrm{z}$ calcd for $\mathrm{C}_{44} \mathrm{H}_{44} \mathrm{Cl}_{3} \mathrm{~N}_{4} \mathrm{O}_{16} 989.1818[\mathrm{M}-\mathrm{H}]^{-}$, found 989.1817.

3-Azidopropyl (Methyl 2,3-di-O-benzoyl- $\beta$-D-glucopyranosyluronate)-(1 $\rightarrow$ 3)-(4,6-O-benzylidene-2-deoxy-2-trichloroacetamido- $\beta$-D-glucopyranoside) (10). Disaccharide 9 (0.45 $\mathrm{g}, 0.45 \mathrm{mmol}$ ) was dissolved in a mixture of hydrazine hydrate $(2.3 \mathrm{mmol}), \mathrm{AcOH}$, and pyridine $\left(\mathrm{NH}_{2} \mathrm{NH}_{2} \cdot \mathrm{H}_{2} \mathrm{O}: \mathrm{AcOH}\right.$ : pyridine, $0.124: 1: 4, \mathrm{v} / \mathrm{v} / \mathrm{v})$. The reaction mixture was stirred overnight at room temperature, diluted with EtOAc, and washed with aqueous $1.0 \mathrm{~mol} \mathrm{~L}^{-1} \mathrm{HCl}$, saturated aqueous $\mathrm{NaHCO}_{3}$ and brine. The organic layer was dried over $\mathrm{Na}_{2} \mathrm{SO}_{4}$, filtered, evaporated to dryness, and purified by silica gel column chromatography (45\% EtOAc in petroleum ether) to yield $\mathbf{1 0}$ $(0.38 \mathrm{~g}, 99 \%)$ as a white solid. ${ }^{1} \mathrm{H}$ NMR $\left(400 \mathrm{MHz}, \mathrm{CDCl}_{3}\right): \delta$ $1.77-1.85(\mathrm{~m}, 2 \mathrm{H}), 3.34(\mathrm{~m}, 2 \mathrm{H}), 3.40(\mathrm{~d}, 1 \mathrm{H}, J=3.0 \mathrm{~Hz})$, $3.50(\mathrm{~b}, 1 \mathrm{H}), 3.55(\mathrm{~m}, 1 \mathrm{H}), 3.74(\mathrm{~m}, 1 \mathrm{H}), 3.83(\mathrm{~s}, 3 \mathrm{H}), 3.96$ 
(m, 1H), 4.05 (dd, 1H, $J=12.4$ and $1.3 \mathrm{~Hz}$ ), 4.09 (d, $1 \mathrm{H}, J=$ $9.8 \mathrm{~Hz}), 4.19(\mathrm{~m}, 1 \mathrm{H}), 4.32(\mathrm{dd}, 1 \mathrm{H}, J=12.3$ and $1.0 \mathrm{~Hz}), 4.42$ $(\mathrm{d}, 1 \mathrm{H}, J=3.4 \mathrm{~Hz}), 4.67(\mathrm{dd}, 1 \mathrm{H}, J=11.2$ and $3.5 \mathrm{~Hz}), 5.10(\mathrm{~d}$, $1 \mathrm{H}, J=8.1 \mathrm{~Hz}), 5.24(\mathrm{~d}, 1 \mathrm{H}, J=6.8 \mathrm{~Hz}), 5.47(\mathrm{~m}, 2 \mathrm{H}), 5.51(\mathrm{~s}$, $1 \mathrm{H}), 7.02(\mathrm{~d}, 1 \mathrm{H}, J=6.6 \mathrm{~Hz}), 7.30-7.40(\mathrm{~m}, 7 \mathrm{H}), 7.46-7.52$ (m, $4 \mathrm{H}), 7.88-7.93(\mathrm{~m}, 4 \mathrm{H}) ;{ }^{13} \mathrm{C}\left(100 \mathrm{MHz}, \mathrm{CDCl}_{3}\right): \delta 29.0$, 48.2, 53.1, 55.2, 66.5, 66.6, 69.1, 70.4, 71.2, 73.8, 74.2, 75.2, 75.8, 92.2, 98.7, 100.4, 100.5, 126.0, 128.2, 128.4, 128.5, 128.9, $129.8,129.0,129.9,130.0,133.4,137.6,162.1,165.1,166.5$, 169.1; HRMS (ESI-TOF): $m / z$ calcd for $\mathrm{C}_{39} \mathrm{H}_{38} \mathrm{Cl}_{3} \mathrm{~N}_{4} \mathrm{O}_{14}$ $891.1450[\mathrm{M}-\mathrm{H}]^{-}$, found 891.1469.

tert-Butyldimethylsilyl (Methyl 2,3-di-O-benzoyl-4-O-levulinoyl- $\beta$-D-glucopyranosyluronate)- $(1 \rightarrow 3)-4,6-0$-benzylidene-2-deoxy-2-trichloroacetamido- $\beta$-D-glucopyranoside (11). Glycosyl donor 8 (2.0 g, $3.0 \mathrm{mmol})$ and glycosyl acceptor 3 (1.3 g, $2.4 \mathrm{mmol})$ were combined and dried by repeated coevaporation with toluene. The residue was dissolved in dry $\mathrm{CH}_{2} \mathrm{Cl}_{2}(20 \mathrm{~mL}), 4 \AA \mathrm{MS}$ were added, and the mixture was stirred at room temperature under nitrogen for $30 \mathrm{~min}$. The reaction mixture was cooled to $0{ }^{\circ} \mathrm{C}$, and TMSOTf $(42 \mu \mathrm{L}$, $0.22 \mathrm{mmol}$ ) was added. The reaction mixture was stirred for 45 min under nitrogen, neutralized by addition of triethylamine, filtered, and evaporated to dryness. Purification by column chromatography (50\% EtOAc in petroleum ether) yielded $\mathbf{1 1}$ $(1.8 \mathrm{~g}, 73 \%)$ as a white solid. ${ }^{1} \mathrm{H} \mathrm{NMR}\left(500 \mathrm{MHz}, \mathrm{CDCl}_{3}\right): \delta$ $0.08(\mathrm{~s}, 3 \mathrm{H}), 0.12(\mathrm{~s}, 3 \mathrm{H}), 0.85(\mathrm{~s}, 9 \mathrm{H}), 2.04(\mathrm{~s}, 3 \mathrm{H}), 2.36-$ $2.64(\mathrm{~m}, 4 \mathrm{H}), 3.49(\mathrm{~b}, 1 \mathrm{H}), 3.67(\mathrm{~m}, 1 \mathrm{H}), 3.77(\mathrm{~s}, 3 \mathrm{H}), 4.06$ $(\mathrm{dd}, 1 \mathrm{H}, J=12.2$ and $1.6 \mathrm{~Hz}), 4.21(\mathrm{~d}, 1 \mathrm{H}, J=10.0 \mathrm{~Hz}), 4.24$ $(\mathrm{dd}, 1 \mathrm{H}, J=12.0$ and $1.3 \mathrm{~Hz}), 4.44(\mathrm{~d}, 1 \mathrm{H}, J=3.4 \mathrm{~Hz}), 4.74$ (dd, $1 \mathrm{H}, J=11.2$ and $3.5 \mathrm{~Hz}), 5.18(\mathrm{~d}, 1 \mathrm{H}, J=7.4 \mathrm{~Hz}), 5.28(\mathrm{~d}$, $1 \mathrm{H}, J=7.8 \mathrm{~Hz}), 5.45-5.51(\mathrm{~m}, 2 \mathrm{H}), 5.53(\mathrm{~s}, 1 \mathrm{H}), 5.60(\mathrm{dd}$, $1 \mathrm{H}, J=9.2$ and $9.2 \mathrm{~Hz}), 6.99(\mathrm{~d}, 1 \mathrm{H}, J=6.8 \mathrm{~Hz}), 7.31-7.38$ (m, 7H), 7.46-7.52 (m, $4 \mathrm{H}), 7.84-7.88(\mathrm{~m}, 4 \mathrm{H}) ;{ }^{13} \mathrm{C}(125$ $\left.\mathrm{MHz}_{\mathrm{CDCl}}\right): \delta-4.9,-4.0,17.8,25.7,27.6,29.6,37.5,53.0$, 57.3, 66.5, 69.1, 69.4, 71.3, 72.1, 72.5, 72.9, 75.7, 92.2, 93.7, $100.0,100.5,126.1,128.1,128.4,128.7,128.8,128.9,133.4$, 133.5, 137.9, 162.0, 164.8, 165.5, 167.2, 171.2, 205.6; HRMS (ESI-TOF): $m / z$ calcd for $\mathrm{C}_{47} \mathrm{H}_{53} \mathrm{Cl}_{3} \mathrm{NO}_{16} \mathrm{Si} 1020.2199$ [M$\mathrm{H}]^{-}$, found 1020.2194 .

(Methyl 2,3-di-O-benzoyl-4-O-levulinoyl- $\beta$-D-glucopyranosyluronate)-(1 $\rightarrow$ 3)-4,6-O-benzylidene-2-deoxy-2-trichloroacetamido- $\alpha$-D-glucopyranoside trichloroacetimidate (12). $\mathrm{Et}_{3} \mathrm{~N} \cdot 3 \mathrm{HF}(0.86 \mathrm{~mL}, 5.3 \mathrm{mmol})$ was added to a solution of disaccharide 11 (1.4 g, $1.3 \mathrm{mmol})$ in THF $(13 \mathrm{~mL})$. The reaction mixture was stirred overnight at room temperature and evaporated to dryness. The residue was purified by silica gel column chromatography (40\% EtOAc in toluene) to yield the desired hemiacetal $(0.76 \mathrm{~g}, 0.83 \mathrm{mmol}, 64 \%)$ as a white foam. The hemiacetal was dissolved in a mixture of $\mathrm{CH}_{2} \mathrm{Cl}_{2}(4 \mathrm{~mL})$ and $\mathrm{CCl}_{3} \mathrm{CN}(8 \mathrm{~mL})$, the mixture was cooled to $0{ }^{\circ} \mathrm{C}$ and DBU $(25 \mu \mathrm{L}, 0.17 \mathrm{mmol})$ was added. The reaction mixture was stirred for $30 \mathrm{~min}$, concentrated to an oil, and purified by silica gel column chromatography (50\% EtOAc in toluene) to yield 12 (0.75 g, 54\%, after two steps) as a white foam. ${ }^{1} \mathrm{H}$ NMR $\left(400 \mathrm{MHz}, \mathrm{CDCl}_{3}\right): \delta 2.04(\mathrm{~s}, 3 \mathrm{H}), 2.35-2.65(\mathrm{~m}, 4 \mathrm{H}), 3.73$ (s, 3H), $3.95(\mathrm{~b}, 1 \mathrm{H}), 4.05(\mathrm{~d}, 1 \mathrm{H}, J=12.6 \mathrm{~Hz}), 4.26-4.37(\mathrm{~m}$, $2 \mathrm{H}), 4.57-4.65(\mathrm{~m}, 2 \mathrm{H}), 4.71(\mathrm{~m}, 1 \mathrm{H}), 5.28(\mathrm{~d}, 1 \mathrm{H}, J=7.6$ $\mathrm{Hz}), 5.33(\mathrm{~s}, 1 \mathrm{H}), 5.46-5.57(\mathrm{~m}, 2 \mathrm{H}), 5.66(\mathrm{dd}, 1 \mathrm{H}, J=8.9$ $\mathrm{Hz}$, both), $6.70(\mathrm{~d}, 1 \mathrm{H}, J=3.1 \mathrm{~Hz}), 6.92(\mathrm{~d}, 1 \mathrm{H}, J=7.8 \mathrm{~Hz})$, 7.15-7.40 (m, 9 H), 7.48-7.55 (m, 2H), 7.90-7.92 (m, 4H), $8.72(\mathrm{~s}, 1 \mathrm{H}) ;{ }^{13} \mathrm{C}\left(125 \mathrm{MHz}, \mathrm{CDCl}_{3}\right): \delta 27.6,29.5,37.5,50.1$, 53.1, 65.2, 68.8, 69.4, 69.9, 70.9, 72.4, 73.0, 74.1, 90.9, 92.1, 95.2, 98.4, 100.8, 126.0, 128.0, 128.4, 128.5, 128.6, 128.8, 129.9,
129.9, 133.6, 133.8, 137.1, 160.3, 161.9, 165.4, 165.5, 166.7, $171.1,205.5$; HRMS (ESI-TOF): $\mathrm{m} / z$ calcd for $\mathrm{C}_{43} \mathrm{H}_{40} \mathrm{Cl}_{6} \mathrm{~N}_{2} \mathrm{NaO}_{16}[\mathrm{M}+\mathrm{Na}]^{+}$1073.0407, found 1073.0374.

3-Azidopropyl (Methyl 2,3-di-O-benzoyl-4-O-levulinoyl- $\beta$ D-glucopyranosyluronate)-(1 $\rightarrow$ 3)-(4,6-O-benzylidene-2deoxy-2-trichloroacetamido- $\alpha$-D-glucopyranosyl)-(1 $\rightarrow$ 4)(methyl 2,3-di-O-benzoyl- $\beta$-D-glucopyranosyluronate)-(1 $\rightarrow$ 3)-(4,6-O-benzylidene-2-deoxy-2-trichloroacetamido- $\beta$ - $D$ glucopyranoside) (13). Glycosyl donor 12 (0.13 g, $0.11 \mathrm{mmol})$ and glycosyl acceptor $10(64 \mathrm{mg}, 72 \mu \mathrm{mol})$ were combined and dried by repeated coevaporation with toluene. The residue was dissolved in dry $\mathrm{CH}_{2} \mathrm{Cl}_{2}(3 \mathrm{~mL}), 4 \AA \mathrm{MS}$ were added, and the mixture was stirred at room temperature under nitrogen for 30 $\min$. The mixture was cooled to $-30^{\circ} \mathrm{C}$ and TMSOTf $(4.7 \mu \mathrm{L}$, $0.02 \mathrm{mmol}$ ) was added. The reaction mixture was stirred for $1 \mathrm{~h}$ at $-30{ }^{\circ} \mathrm{C}$ under nitrogen, neutralized by addition of triethylamine, filtered, and concentrated to an oil. Purification by silica gel column chromatography (30\% EtOAc in toluene) yielded 13 (40 mg, 32\%) as a white solid. ${ }^{1} \mathrm{H}$ NMR (400 MHz, $\left.\mathrm{CDCl}_{3}\right): \delta 1.76-1.85(\mathrm{~m}, 2 \mathrm{H}), 2.04(\mathrm{~s}, 3 \mathrm{H}), 2.37-2.60(\mathrm{~m}$, $4 \mathrm{H}), 3.33(\mathrm{~m}, 2 \mathrm{H}), 3.52(\mathrm{~b}, 1 \mathrm{H}), 3.55(\mathrm{~m}, 1 \mathrm{H}), 3.64(\mathrm{~b}, 1 \mathrm{H})$, $3.72(\mathrm{~m}, 1 \mathrm{H}), 3.74(\mathrm{~s}, 3 \mathrm{H}), 3.84(\mathrm{~s}, 3 \mathrm{H}), 3.96(\mathrm{~m}, 1 \mathrm{H}), 4.04-$ $4.09(\mathrm{~m}, 2 \mathrm{H}), 4.19-4.34(\mathrm{~m}, 5 \mathrm{H}), 4.39(\mathrm{~d}, 1 \mathrm{H}, J=3.5 \mathrm{~Hz})$, $4.52(\mathrm{~m}, 1 \mathrm{H}), 4.59$ (dd, $1 \mathrm{H}, J=8.9 \mathrm{~Hz}$, both), 4.62 (d, $1 \mathrm{H}, J=$ $2.5 \mathrm{~Hz}), 4.70(\mathrm{dd}, 1 \mathrm{H}, J=3.5$ and $11.1 \mathrm{~Hz}), 5.03(\mathrm{~d}, 1 \mathrm{H}, J=8.2$ $\mathrm{Hz}), 5.16(\mathrm{~d}, 1 \mathrm{H}, J=6.2 \mathrm{~Hz}), 5.18(\mathrm{~d}, 1 \mathrm{H}, J=6.7 \mathrm{~Hz}), 5.28(\mathrm{~d}$, $1 \mathrm{H}, J=3.3 \mathrm{~Hz}), 5.40(\mathrm{dd}, 1 \mathrm{H}, J=6.8 \mathrm{~Hz}$, both), $5.43(\mathrm{~s}, 1 \mathrm{H})$, $5.43-5.62(\mathrm{~m}, 4 \mathrm{H}), 5.49(\mathrm{~s}, 1 \mathrm{H}), 6.60(\mathrm{~d}, 1 \mathrm{H}, J=6.6 \mathrm{~Hz}), 6.87$ $(\mathrm{d}, 1 \mathrm{H}, J=6.8 \mathrm{~Hz}), 7.30-7.38(\mathrm{~m}, 12 \mathrm{H}), 7.43-7.52(\mathrm{~m}, 8 \mathrm{H})$, $7.80-7.91(\mathrm{~m}, 10 \mathrm{H}) ;{ }^{13} \mathrm{C}\left(100 \mathrm{MHz}, \mathrm{CDCl}_{3}\right): \delta 27.6,29.0$, 29.7, 37.5, 48.1, 49.9, 53.0, 53.1, 55.0, 64.1, 66.4, 66.6, 68.9, 69.0, 69.6, 71.3, 71.4, 71.4, 72.2, 72.4, 73.6, 73.7, 74.5, 74.6, 74.7, 75.3, 92.0, 92.1, 97.7, 98.7, 98.8, 100.0, 100.5, 100.6, $125.3,126.0,126.1,127.9,128.1,128.2,128.4,128.5,128.7$, $129.0,129.8,129.9,130.0,137.4,137.6,137.9,161.6,162.1$, 164.9, 165.0, 165.4, 165.4, 167.4, 168.2, 171.2, 205.6; HRMS (ESI-TOF): $m / z$ calcd for $\mathrm{C}_{80} \mathrm{H}_{76} \mathrm{Cl}_{6} \mathrm{~N}_{5} \mathrm{O}_{29}[\mathrm{M}-\mathrm{H}]^{-}$ 1780.2757, found 1780.2757 .

3-Azidopropyl (Methyl 2,3-di-O-benzoyl-4-O-levulinoyl- $\beta$ D-glucopyranosyluronate)-(1 $\rightarrow$ 3)-(4,6-di-O-chloroacetyl-2deoxy-2-trichloroacetamido- $\beta$-D-glucopyranosyl)- $(1 \rightarrow 4)$ (methyl 2,3-di-O-benzoyl- $\beta$-D-glucopyranosyluronate)-(1 $\rightarrow$ 3)-(4,6-O-benzylidene-2-deoxy-2-trichloroacetamido- $\beta$ - $D$ glucopyranoside) (15). Glycosyl donor 14 (220 mg, 0.11 $\mathrm{mmol}$ ) was prepared according to literature ${ }^{14}$ and dried together with glycosyl acceptor $10(130 \mathrm{mg}, 0.07 \mathrm{mmol})$ by repeated coevaporation with toluene. The mixture was dissolved in dry $\mathrm{CH}_{2} \mathrm{Cl}_{2}(4 \mathrm{~mL}), 4 \AA \mathrm{MS}$ was added, and the mixture was stirred at room temperature under nitrogen for 30 min. The reaction mixture was cooled to $-60{ }^{\circ} \mathrm{C}$, and TMSOTf $(13.2 \mu \mathrm{L}, 0.5 \mathrm{mmol})$ was added. Upon completion of the reaction (45 $\mathrm{min}$ ), triethylamine was added, and the mixture was concentrated to an oil. Purification by silica gel column chromatography (30\% EtOAc in toluene) yielded 3 as a white solid (90 mg, 33\%). ${ }^{1} \mathrm{H}$ NMR $\left(400 \mathrm{MHz}, \mathrm{CDCl}_{3}\right): \delta$ $1.78-1.87(\mathrm{~m}, 2 \mathrm{H}), 2.03(\mathrm{~s}, 3 \mathrm{H}), 2.33-2.65(\mathrm{~m}, 4 \mathrm{H}), 3.27-$ $3.35(\mathrm{~m}, 3 \mathrm{H}), 3.41-3.58(\mathrm{~m}, 4 \mathrm{H}), 3.69-3.85(\mathrm{~m}, 3 \mathrm{H}), 3.76(\mathrm{~s}$, $3 \mathrm{H}), 3.77(\mathrm{~s}, 3 \mathrm{H}), 3.96(\mathrm{~m}, 1 \mathrm{H}), 3.99-4.15(\mathrm{~m}, 6 \mathrm{H}), 4.28-4.40$ $(\mathrm{m}, 3 \mathrm{H}), 4.64(\mathrm{~m}, 2 \mathrm{H}), 4.79(\mathrm{~d}, 1 \mathrm{H}, J=6.8 \mathrm{~Hz}), 5.07(\mathrm{~d}, 1 \mathrm{H}, J$ $=7.8 \mathrm{~Hz}), 5.09(\mathrm{~d}, 1 \mathrm{H}, J=7.4 \mathrm{~Hz}), 5.20(\mathrm{~d}, 1 \mathrm{H}, J=7.0 \mathrm{~Hz})$, $5.25(\mathrm{dd}, 1 \mathrm{H}, J=9.5 \mathrm{~Hz}, 7.8 \mathrm{~Hz}), 5.36-5.60(\mathrm{~m}, 6 \mathrm{H}), 6.67(\mathrm{~d}$, $1 \mathrm{H}, J=6,8 \mathrm{~Hz}), 6.95(\mathrm{~d}, 1 \mathrm{H}, J=6,4 \mathrm{~Hz}), 7.17-7.40(\mathrm{~m}, 9 \mathrm{H})$, $7.45-7.55(\mathrm{~m}, 7 \mathrm{H}), 7.82-7.92(\mathrm{~m}, 9 \mathrm{H}) ;{ }^{13} \mathrm{C}(100 \mathrm{MHz}$, 
$\left.\mathrm{CDCl}_{3}\right) \delta 27.6,29.0,29.6,37.6,40.3,40.6,48.1,53.0,53.3$, 55.0, 55.6, 62.2, 66.5, 66.6, 69.0, 69.3, 70.4, 70.5, 71.1, 71.4, 71.4, 71.9, 72.1, 72.4, 72.5, 73.9, 74.1, 74.5, 75.7, 92.0, 92.1, 97.2 , 98.5, 100.3, 100.5, 100.6, 125.9, 126.0, 128.2, 128.4, 128.6, $128.8,128.9,129.0,129.3,129.7,129.8,129.9,130.0,133.4$, $133.5,133.6,137.5,161.8,162.1,164.7,165.0,165.3,165.5$, 166.2, 166.5, 166.6, 167.8, 171.0, 205.5; HRMS (ESI-TOF): $\mathrm{m} /$ $z$ calcd for $\mathrm{C}_{77} \mathrm{H}_{74} \mathrm{Cl}_{8} \mathrm{~N}_{5} \mathrm{O}_{31}[\mathrm{M}-\mathrm{H}]$ 1844.1876, found 1844.2232 .

3-Azidopropyl (Methyl 2,3-di-O-benzoyl-4-O-levulinoyl- $\beta$ D-glucopyranosyluronate)-(1 $\rightarrow$ 3)-(2-deoxy-2-trichloroacetamido- $\beta$-D-glucopyranosyl)-( $\rightarrow$ 4)-(methyl 2,3-di-O-benzoyl- $\beta$-D-glucopyranosyluronate)- $(1 \rightarrow 3)-(4,6-0$-benzylidene-2-deoxy-2-trichloroacetamido- $\beta$-D-glucopyranoside) (16). Tetrasaccharide 15 (90 mg, $0.049 \mathrm{mmol}$ ) was dissolved in a mixture of thiourea $(30.4 \mathrm{mg}, 0.4 \mathrm{mmol})$ in pyridine:EtOH $(1: 1, \mathrm{v} / \mathrm{v}, 1.5 \mathrm{~mL})$, and the reaction mixture was allowed to stir for $2 \mathrm{~h}$ at $80^{\circ} \mathrm{C}$. The completion of the reaction was confirmed by RP HPLC analysis (Scheme 4a). The mixture was concentrated and purified by silica gel column chromatography $\left(10 \% \mathrm{MeOH} / \mathrm{CH}_{2} \mathrm{Cl}_{2}\right)$ to afford pure tetrasaccharide 16 (60 $\mathrm{mg}, 73 \%)$ as a white solid. ${ }^{1} \mathrm{H}$ NMR $\left(500 \mathrm{MHz}^{\mathrm{CDCl}}{ }_{3}\right): \delta$ 1.75-1.85 (m, 2H), $2.03(\mathrm{~S}, 3 \mathrm{H}), 2.32-2.64(\mathrm{~m}, 4 \mathrm{H}), 3.16$ $(\mathrm{dd}, 1 \mathrm{H}, J=11.9 \mathrm{~Hz}, 7.3 \mathrm{~Hz}), 3.25(\mathrm{dd}, 1 \mathrm{H}, J=11.9 \mathrm{~Hz}, 7.2$ $\mathrm{Hz}), 3.33(\mathrm{~m}, 2 \mathrm{H}), 3.39(\mathrm{~m}, 1 \mathrm{H}), 3.48(\mathrm{~b}, 1 \mathrm{H}), 3.50-3.56(\mathrm{~m}$, $2 \mathrm{H}), 3.71(\mathrm{~s}, 3 \mathrm{H}), 3.73(\mathrm{~s}, 3 \mathrm{H}), 3.75(\mathrm{~m}, 1 \mathrm{H}), 3.95(\mathrm{~m}, 1 \mathrm{H})$, $4.00(\mathrm{~d}, 1 \mathrm{H}, J=2.4 \mathrm{~Hz}), 4.03(\mathrm{~d}, 1 \mathrm{H}, J=12.1 \mathrm{~Hz}), 4.11(\mathrm{~d}, 1 \mathrm{H}$, $J=8.7 \mathrm{~Hz}), 4.21(\mathrm{~d}, 1 \mathrm{H}, J=9.6 \mathrm{~Hz}), 4.30(\mathrm{~d}, 1 \mathrm{H}, J=12.1 \mathrm{~Hz})$, $4.37-4.42(\mathrm{~m}, 3 \mathrm{H}), 4.63(\mathrm{dd}, 1 \mathrm{H}, J=11.1 \mathrm{~Hz}, 3.2 \mathrm{~Hz}), 4.95(\mathrm{~d}$, $1 \mathrm{H}, J=7.1 \mathrm{~Hz}), 5.02(\mathrm{~d}, 1 \mathrm{H}, J=8.2 \mathrm{~Hz}), 5.05(\mathrm{~d}, 1 \mathrm{H}, J=8.2$ $\mathrm{Hz}), 5.20(\mathrm{~d}, 1 \mathrm{H}, J=7.1 \mathrm{~Hz}), 5.38-5.52(\mathrm{~m}, 5 \mathrm{H}), 5.61(\mathrm{dd}$, $1 \mathrm{H}, J=9.1 \mathrm{~Hz}$, both), $6.86(\mathrm{~b}, 1 \mathrm{H}), 7.08$ (b, 1H), 7.22-7.91 $(\mathrm{m}, 25 \mathrm{H}),{ }^{13} \mathrm{C}\left(100 \mathrm{MHz}, \mathrm{CDCl}_{3}\right) \delta 27.6,29.0,29.5,37.5,48.1$, 53.1, 53.2, 54.9, 55.0, 61.8, 66.4, 66.6, 68.0, 69.0, 69.1, 71.2, 71.5, 71.9, 72.1, 73.2, 74.1, 74.1, 74.2, 74.6, 74.7, 75.7, 92.1, 92.2, 97.9, 98.7, 100.4, 100.6, 100.7, 126.1, 128.2, 128.4, 128.6, $128.7,128.9,129.0,129.5,129.7,129.8,129.9,130.0,133.3$, $133.4,133.5,133.5,137.6,161.8,162.1,165.0,165.1,165.5$, 165.6, 167.3, 168.0, 171.2, 205.6; HRMS (ESI-TOF): $\mathrm{m} / z$ calcd for $\mathrm{C}_{73} \mathrm{H}_{72} \mathrm{Cl}_{6} \mathrm{~N}_{5} \mathrm{O}_{29}[\mathrm{M}-\mathrm{H}]^{-}$1692.2444, found 1692.2448 .

3-Azidopropyl (Methyl 2,3-di-O-benzoyl-4-O-levulinoyl- $\beta$ D-glucopyranosyluronate)-(1 $\rightarrow$ 3)-(2-deoxy-4,6-di-O-sulfonato-2-trichloroacetamido- $\beta$-D-glucopyranosyl)- $(1 \rightarrow 4)$ (methyl 2,3-di-O-benzoyl- $\beta$-D-glucopyranosyluronate)-(1 $\rightarrow$ 3)-(2-deoxy-2-trichloroacetamido- $\beta$-D-glucopyranoside) (18). Tetrasaccharide $16(10 \mathrm{mg}, 5.9 \mu \mathrm{mol})$ was dissolved in DMF $(0.6 \mathrm{~mL})$, and $\mathrm{SO}_{3}$.TMA (58 equiv) was added (ii/ Scheme 4). The reaction mixture was stirred overnight at 50 ${ }^{\circ} \mathrm{C}$, cooled to room temperature, quenched with $\mathrm{MeOH}$, evaporated to dryness, and the residue was subjected to a semipreparative RP HPLC (b/Scheme 4). The product fractions were lyophilized and the purified residue (17: HRMS (ESI-TOF): $m / z$ calcd for $\mathrm{C}_{73} \mathrm{H}_{72} \mathrm{Cl}_{6} \mathrm{~N}_{5} \mathrm{O}_{35} \mathrm{~S}_{2}$ : $1852.1580[\mathrm{M}-\mathrm{H}]^{-}$, found 1852.1368$)$ was dissolved in $0.1 \%$ aqueous TFA (iii in Scheme 4). The mixture was stirred for $5 \mathrm{~h}$ at room temperature, neutralized with $1 \mathrm{~mol} \mathrm{~L}^{-1}$ triethylammonium acetate and evaporated to dryness. The residue was purified by semipreparative RP HPLC (c/Scheme 4) to obtain pure 18 as a white solid $(1.7 \mathrm{mg}, 16 \%$ overall yield calculated from 16). ${ }^{1} \mathrm{H}$ NMR (500 MHz, $\left.\mathrm{CD}_{3} \mathrm{OD}\right): \delta 1.71-1.77(\mathrm{~m}$, $2 \mathrm{H}), 1.98(\mathrm{~s}, 3 \mathrm{H}), 2.33-2.46(\mathrm{~m}, 2 \mathrm{H}), 2.60(\mathrm{~m}, 2 \mathrm{H}), 3.33(\mathrm{~m}$, $2 \mathrm{H}), 3.50-3.55(\mathrm{~m}, 2 \mathrm{H}), 3.75(\mathrm{~m}, 2 \mathrm{H}), 3.78(\mathrm{~s}, 3 \mathrm{H}), 3.82(\mathrm{~s}$,
$3 \mathrm{H}), 3.84-3.91(\mathrm{~m}, 2 \mathrm{H}), 3.96-4.04(\mathrm{~m}, 4 \mathrm{H}), 4.15(\mathrm{~b}, 1 \mathrm{H})$, $4.26(\mathrm{dd}, 1 \mathrm{H}, J=11.4 \mathrm{~Hz}, 2.2 \mathrm{~Hz}), 4.31(\mathrm{~d}, 1 \mathrm{H}, J=9.7 \mathrm{~Hz})$, $4.33(\mathrm{~m}, 1 \mathrm{H}), 4.44(\mathrm{~d}, 1 \mathrm{H}, J=7.8 \mathrm{~Hz}), 4.50(\mathrm{dd}, 1 \mathrm{H}, J=8.9$ $\mathrm{Hz}$, both), $4.57(\mathrm{~d}, 1 \mathrm{H}, J=9.1 \mathrm{~Hz}), 4.87$ ( $1 \mathrm{H}$ according to HSQC, overlapping with $\left.\mathrm{H}_{2} \mathrm{O}\right), 4.92(\mathrm{~d}, 1 \mathrm{H}, J=8.1 \mathrm{~Hz}), 5.13$ $(\mathrm{d}, 1 \mathrm{H}, J=7.4 \mathrm{~Hz}), 5.17(\mathrm{~d}, 1 \mathrm{H}, J=8.0 \mathrm{~Hz}), 5.30(\mathrm{dd}, 1 \mathrm{H}, J=$ $8.7 \mathrm{~Hz}, 8.1 \mathrm{~Hz}$ ), 5.49 (dd, $1 \mathrm{H}, \mathrm{J}=9.8 \mathrm{~Hz}, 9.4 \mathrm{~Hz}), 5.50-5.59$ $(\mathrm{m}, 2 \mathrm{H}), 5.67$ (dd, $1 \mathrm{H}, \mathrm{J}=8.8 \mathrm{~Hz}$, both), 7.30-7.38 (m, $8 \mathrm{H})$, $7.45-7.52(\mathrm{~m}, 4 \mathrm{H}), 7.77-7.88(\mathrm{~m}, 8 \mathrm{H}) ;{ }^{13} \mathrm{C}(125 \mathrm{MHz}$, $\left.\mathrm{CD}_{3} \mathrm{OD}\right) \delta 27.3,27.9,28.7,36.9,48.1,52.0,52.0,52.9,53.9$, $60.9,65.8,67.6,67.6,69.3,71.7,71.9,71.9,72.2,73.4,73.4$, 73.8, 74.2, 74.6, 74.9, 75.1, 79.2, 92.4, 92.5, 98.2, 100.4, 101.0, $101.3,127.8,127.9,128.0,128.1,129.0,129.1,129.4,129.6$, $129.9,132.7,132.8,132.9,133.1,162.3,162.8,164.9,165.5$, 165.7, 165.8, 167.4, 168.8, 171.3, 207.1; HRMS (ESI-TOF): $m / z$ calcd for $\mathrm{C}_{66} \mathrm{H}_{67} \mathrm{Cl}_{6} \mathrm{~N}_{5} \mathrm{O}_{35} \mathrm{~S}_{2}: 881.5595[(\mathrm{M}-2 \mathrm{H}) / 2]^{2-}$, found 881.5683 .

3-Azidopropyl (Methyl 2,3-di-O-benzoyl-4-O-levulinoyl- $\beta$ D-glucopyranosyluronate)-(1 $\rightarrow$ 3)-(4,6-di-O-acetyl-2-deoxy2-trichloroacetamido- $\beta$-D-glucopyranosyl)-(1 $\rightarrow$ 4)-(methyl 2,3-di-O-benzoyl- $\beta$-D-glucopyranosyluronate)-(1 $\rightarrow 3)-(2-$ deoxy-4,6-di-O-sulfonato-2-trichloroacetamido- $\beta$ - $D$-glucopyranoside) (21). Tetrasaccharide $16(10 \mathrm{mg}, 5.9 \mu \mathrm{mol})$ was dissolved in a mixture of $\mathrm{Ac}_{2} \mathrm{O}(0.4 \mathrm{~mL})$ and pyridine $(0.6 \mathrm{~mL})$. The mixture was stirred overnight at room temperature, diluted with ethyl acetate $(10 \mathrm{~mL})$, and washed with saturated aqueous $\mathrm{NaHCO}_{3}(5 \mathrm{~mL})$ and $10 \%$ aqueous $\mathrm{KH}_{2} \mathrm{PO}_{4}(5 \mathrm{~mL})$. The organic layer was separated and evaporated to dryness. The completion of the acetylation (iv/Scheme 4) was confirmed by an RP HPLC analysis (d/Scheme 4) and the crude residue (19) was then dissolved in $80 \%$ aqueous $\mathrm{AcOH}(3 \mathrm{~mL})(\mathrm{v} /$ Scheme 4). The mixture was stirred for $1 \mathrm{~h}$ at $100{ }^{\circ} \mathrm{C}$, evaporated to dryness and the residue was subjected to a semipreparative RP-HPLC (e/Scheme 4). The product fractions were lyophilized and the purified residue (20: HRMS (ESI-TOF): $m / z$ calcd for $\mathrm{C}_{70} \mathrm{H}_{72} \mathrm{Cl}_{6} \mathrm{~N}_{5} \mathrm{O}_{31}$ $1688.2342[\mathrm{M}-\mathrm{H}]^{-}$, found 1688.2198) was exposed to the treatment with $\mathrm{SO}_{3}$.TMA as described for $\mathbf{1 7}$ above (ii/Scheme 4). RP HPLC (f/Scheme 4) purification gave pure 21 as a white solid (2.3 mg, $21 \%$ overall yield from 16). ${ }^{1} \mathrm{H}$ NMR (500 $\left.\mathrm{MHz}, \mathrm{CD}_{3} \mathrm{OD}\right): \delta 1.74-1.80(\mathrm{~m}, 2 \mathrm{H}), 1.88(\mathrm{~s}, 3 \mathrm{H}), 1.98(\mathrm{~s}$, $3 \mathrm{H}), 2.03(\mathrm{~s}, 3 \mathrm{H}), 2.31-2.46(\mathrm{~m}, 2 \mathrm{H}), 2.59-2.62(\mathrm{~m}, 2 \mathrm{H})$, $3.06(\mathrm{dd}, 1 \mathrm{H}, J=11.2 \mathrm{~Hz}, 6.9 \mathrm{~Hz}), 3.34(\mathrm{~m}, 2 \mathrm{H}), 3.52-3.58$ $(\mathrm{m}, 2 \mathrm{H}), 3.74(\mathrm{~s}, 3 \mathrm{H}), 3.76(\mathrm{~m}, 1 \mathrm{H}), 3.80(\mathrm{~s}, 3 \mathrm{H}), 3.83(\mathrm{dd}$, $1 \mathrm{H}, J=8.3 \mathrm{~Hz}, 10.8 \mathrm{~Hz}), 3.92(\mathrm{~m}, 1 \mathrm{H}), 4.90-3.94(\mathrm{~m}, 2 \mathrm{H})$, $4.14-4.27(\mathrm{~m}, 4 \mathrm{H}), 4.30(\mathrm{~d}, 1 \mathrm{H}, J=10.0 \mathrm{~Hz}), 4.50(\mathrm{~d}, 1 \mathrm{H}, J=$ $8.5 \mathrm{~Hz}), 4.53(\mathrm{dd}, 1 \mathrm{H}, \mathrm{J}=8.7 \mathrm{~Hz}$, both), $4.90(\mathrm{~d}, 1 \mathrm{H}, J=8.4$ $\mathrm{Hz}), 4.94(\mathrm{~d}, 1 \mathrm{H}, J=3.0 \mathrm{~Hz}), 5.09(\mathrm{~d}, 1 \mathrm{H}, J=7.8 \mathrm{~Hz}), 5.12$ (d, $1 \mathrm{H}, J=7.0 \mathrm{~Hz}), 5.22(\mathrm{dd}, 1 \mathrm{H}, \mathrm{J}=9.7 \mathrm{~Hz}, 7.9 \mathrm{~Hz}), 5.26(\mathrm{~d}, 1 \mathrm{H}$, $J=3.6 \mathrm{~Hz}$ ), $5.30(\mathrm{dd}, 1 \mathrm{H}, \mathrm{J}=9.7 \mathrm{~Hz}$, both), 5.43 (dd, $1 \mathrm{H}, J=$ $8.5 \mathrm{~Hz}, 7.1 \mathrm{~Hz}$ ), 5.52 (dd, $1 \mathrm{H}, J=8.5 \mathrm{~Hz}$, both), $5.62(\mathrm{dd}, 1 \mathrm{H}, J$ $=9.5 \mathrm{~Hz}$, both), 7.31-7.39 (m, 8H), 7.46-7.53 (m, 4H), 7.77-7.84 (m, 6H), 7.91-7.93 (m, 2H); ${ }^{13} \mathrm{C}(125 \mathrm{MHz}$, $\left.\mathrm{CD}_{3} \mathrm{OD}\right) \delta 19.4,27.3,28.0,28.7,36.9,48.0,52.0,52.2,53.6$, 53.8, 61.6, 66.1, 68.1, 68.4, 69.6, 70.8, 71.5, 72.1, 72.3, 72.6, 73.1, 73.4, 73.9, 74.9, 75.0, 75.4, 92.4, 92.7, 99.8, 100.1, 101.0, $101.1,127.9,128.0,128.1,128.8,128.9,129.0,129.4,129.5$, $129.6,129.7,129.8,132.7,133.0,133.2,162.3,162.7,165.0$, $165.1,165.5,165.6,167.4,168.5,170.5,170.8,171.4,206.9$; HRMS (ESI-TOF): $m / z$ calcd for $\left[\mathrm{C}_{70} \mathrm{H}_{71} \mathrm{Cl}_{6} \mathrm{~N}_{5} \mathrm{O}_{37} \mathrm{~S}_{2}\right] /$ 2:923.5706 $[(\mathrm{M}-2 \mathrm{H}) / 2]^{2-}$, found 923.5815.

3-Azidopropyl (Methyl 2,3-di-O-benzoyl-4-O-levulinoyl- $\beta$ D-glucopyranosyluronate)-(1 $\rightarrow$ 3)-(4,6-di-O-sulfonato-2- 
deoxy-2-trichloroacetamido- $\beta$-D-glucopyranosyl)-(1 $\rightarrow 4)$ (methyl 2,3-di-O-benzoyl- $\beta$-D-glucopyranosyluronate)-(1 $\rightarrow$ 3)-(2-deoxy-4,6-di-O-sulfonato-2-trichloroacetamido- $\beta$ - $D$ glucopyranoside) (23). A solution of tetrasaccharide 16 (10 $\mathrm{mg}, 5.9 \mu \mathrm{mol})$ in $80 \% \mathrm{AcOH}(3.0 \mathrm{~mL})$ was stirred for $1 \mathrm{~h}$ at $100{ }^{\circ} \mathrm{C}$, allowed to cool down to room temperature, evaporated to dryness, and the residue was subjected to a semipreparative RP HPLC (g/Scheme 4). The product fractions were lyophilized and the purified residue (22: HRMS (ESI-TOF): $m / z$ calcd for $\mathrm{C}_{66} \mathrm{H}_{68} \mathrm{Cl}_{6} \mathrm{~N}_{5} \mathrm{O}_{29}: 1604.2131[\mathrm{M}-\mathrm{H}]^{-}$, found 1604.2143) was exposed to the treatment with $\mathrm{SO}_{3} \cdot \mathrm{TMA}$ as described for 17 above (ii/Scheme 4). The crude product mixture was purified by semipreparative RP-HPLC ( $\mathrm{h} /$ Scheme 4) to obtain pure $23(2.5 \mathrm{mg}, 22 \%$ overall yield from 16$)$ as a white solid. ${ }^{1} \mathrm{H}$ NMR (500 MHz, $\left.\mathrm{CD}_{3} \mathrm{OD}\right): \delta 1.78-1.85(\mathrm{~m}$, $2 \mathrm{H}), 2.03(\mathrm{~S}, 3 \mathrm{H}), 2.38-2.52(\mathrm{~m}, 2 \mathrm{H}), 2.66(\mathrm{~m}, 2 \mathrm{H}), 3.33(\mathrm{~m}$, $2 \mathrm{H}), 3.60(\mathrm{~m}, 1 \mathrm{H}), 3.77(\mathrm{dd}, 1 \mathrm{H}, J=12.3 \mathrm{~Hz}, 7.6 \mathrm{~Hz}), 3.83(\mathrm{~s}$, $3 \mathrm{H}), 3.87(\mathrm{dd}, 1 \mathrm{H}, J=11.2 \mathrm{~Hz}, 2.9 \mathrm{~Hz}), 3.94(\mathrm{~s}, 3 \mathrm{H}), 3.96(\mathrm{~m}$, $1 \mathrm{H}), 4.00-4.06(\mathrm{~m}, 3 \mathrm{H}), 4.19-4.22(\mathrm{~m} .2 \mathrm{H}), 4.25-4.32(\mathrm{~m}$, $3 \mathrm{H}), 4.37(\mathrm{~d}, 1 \mathrm{H}, J=9.8 \mathrm{~Hz}), 4.47-4.53(\mathrm{~m}, 2 \mathrm{H}), 4.53(\mathrm{~d}, 1 \mathrm{H}$, $\mathrm{J}=8.3 \mathrm{~Hz}$ ), 4.89 (d, $1 \mathrm{H}, J=3.3 \mathrm{~Hz}), 4.93$ (1H overlapped with $\left.\mathrm{H}_{2} \mathrm{O}\right), 4.99(\mathrm{~d}, 1 \mathrm{H}, J=8.2 \mathrm{~Hz}), 5.14(\mathrm{~d}, 1 \mathrm{H}, J=7.8 \mathrm{~Hz}), 5.19$ $(\mathrm{d}, 1 \mathrm{H}, J=7.7 \mathrm{~Hz}), 5.39(\mathrm{dd}, 1 \mathrm{H}, J=7.8 \mathrm{~Hz}, 9.6 \mathrm{~Hz}), 5.50-$ $5.57(\mathrm{~m}, 3 \mathrm{H}), 5.62(\mathrm{dd}, 1 \mathrm{H}, \mathrm{J}=9.5 \mathrm{~Hz}$, both), 7.36-7.41 (m, $6 \mathrm{H}), 7.43-7.47(\mathrm{~m}, 2 \mathrm{H}), 7.50-7.58(\mathrm{~m}, 4 \mathrm{H}) ; 7.82-7.86(\mathrm{~m}$, $4 \mathrm{H}), 7.90-7.92(\mathrm{~m}, 6 \mathrm{H}) ;{ }^{13} \mathrm{C}\left(125 \mathrm{MHz}, \mathrm{CDCl}_{3}\right): \delta ; 27.4$, 28.0, 28.7, 37.0, 48.0, 52.0, 52.4, 53.5, 53.8, 66.1, 67.5, 68.0, 69.3, 71.9, 72.0, 72.2, 73.1, 73.2, 73.5, 73.7, 74.0, 74.5, 75.4, 75.6, 75.6, 92.6, 92.7, 99.6, 100.4, 101.2, 101.3, 127.9, 127.9, $128.0,128.2,129.0,129.4,129.5,129.6,129.6,129.7,129.8$, $132.7,132.7,132.8,133.1,162.4,162.7,165.0,165.2,165.7$, $166.3,167.4,168.3,171.4,207.0$; HRMS : $\left[\mathrm{C}_{66} \mathrm{H}_{67} \mathrm{Cl}_{6} \mathrm{~N}_{5} \mathrm{O}_{41} \mathrm{~S}_{4}\right] / 2: 962.5163[(\mathrm{M}-2 \mathrm{H}) / 2]^{2-}$, found 961.5269.

Preparation of Carboxyrhodamine-Labeled CSs (24-26, 29, 30). Exposing the carboxylates of the glucuronic acid units (i/ Scheme 5): The protected chondroitin sulfate precursors (18, 21, or $23,0.3 \mu \mathrm{mol}$ ) were dissolved in $0.1 \mathrm{~mol} \mathrm{~L}^{-1}$ aqueous $\mathrm{NaOH}(0.50 \mathrm{~mL})$. The mixtures were mixed for $3 \mathrm{~h}$ at $55^{\circ} \mathrm{C}$, neutralized by addition of $1.0 \mathrm{~mol} \mathrm{~L}^{-1}$ aqueous $\mathrm{NH}_{4} \mathrm{Cl}(55 \mu \mathrm{L})$ and evaporated to dryness. Removal of the trichloroacetyl groups (ii/Scheme 5): The residues were dissolved in concentrated aqueous ammonia $(0.50 \mathrm{~mL})$. The mixtures were mixed for $4 \mathrm{~d}$ at $55{ }^{\circ} \mathrm{C}$ and evaporated to dryness. Acetylation of the galactosamine residues (ii and iii/Scheme 5): The residues were dissolved in aqueous acetonitrile $\left(\mathrm{MeCN}: \mathrm{H}_{2} \mathrm{O}, 1: 9, \mathrm{v} / \mathrm{v}\right.$, $0.50 \mathrm{~mL})$ and $\mathrm{Et}_{3} \mathrm{~N}(50 \mu \mathrm{L})$ and acetic anhydride $(25 \mu \mathrm{L})$ were added. The mixtures were mixed at ambient temperature for 2 $\mathrm{h}$, evaporated to dryness and the residues were dissolved in concentrated ammonia (iv/Scheme 5). The mixtures were mixed for $5 \mathrm{~h}$ at $55^{\circ} \mathrm{C}$ and evaporated to dryness. Labeling with carboxyrhodamine dye (v/Scheme 5): The obtained crude residues of the azidopropyl modified chondroitin sulfates were finally dissolved in a mixture of DMF and water $(1: 1, \mathrm{v} / \mathrm{v}, 0.20$ $\mathrm{mL}$ ) and exposed to a SPAAC conjugation with dibenzylcyclooctyne-PEG-5/6-carboxyrhodamine ( $0.6 \mu \mathrm{mol}, 2.0$ equiv in comparison to 18,21 , and 23 ). The mixtures were mixed overnight at $55{ }^{\circ} \mathrm{C}$ and subjected to RP HPLC (a-d/Scheme $5)$ to obtain pure rhodamine-labeled chondroitin sulfates 2426. Isolated yields of the products according to UV-absorbance at $501 \mathrm{~nm}$ were ca. $60 \%$ (overall yields calculated from 18, 21, and 23). The benzylidene protections of 9 and 12 were removed and the exposed hydroxyl groups sulfated using exactly the same procedure as described for the transformation of 16 to 23 above. The acyl protected precursors (27 and 28) were purified by RP HPLC and exposed then to the treatments with aqueous $\mathrm{NaOH}$, concentrated ammonia, acetic anhydride and carboxyrhodamine dye as described for the transformation of 18, 21, and 23 to 24-26 above. Isolated yields of 29 and 30 were 11 and $12 \%$, respectively (overall yields calculated from 9 and 12). The authenticity of the products was verified by MS (ESI-TOF) spectroscopy (Table 1).

Synthesis of CS-Oligonucleotide Conjugates (32, 33, and 34). The cyclooctyne modified oligonucleotide (31) was synthesized on a $1.0 \mu \mathrm{mol}$ scale using an automatic DNA/ RNA-synthesizer (commercially available phosphoramidite building blocks of 2 -deoxynucleosides and 2-(bicyclo[6.1.0]non-4-yn-9-yl)ethan-1-ol were used) and homogenized by RPHPLC. The CS precursors (18, 21, and 23, $20 \mathrm{nmol}$ each) were exposed to global deprotection $/ N$-acetylation as above. The crude residues of the azidopropyl modified CS-tetrasaccharides were dissolved in an aqueous solution of 31 ( 1.5 equiv, $30 \mathrm{nmol}$ in $30 \mu \mathrm{L}$ of $\mathrm{H}_{2} \mathrm{O}$ ), the mixtures were incubated overnight at 55 ${ }^{\circ} \mathrm{C}$ and subjected then to RP HPLC (cf. HPLC conditions in Scheme 6, conversion yield for 32, 33, and 34 according to peak areas: 70, 75, and 90\%, respectively). The product fractions were lyophilized to dryness to obtain homogenized CS-oligonucleotide conjugates 32,33 , and 34 . The authenticity of the products was verified by MS (ESI-TOF) spectroscopy (cf. Scheme 6 and the Supporting Information).

HC Neuron Cell Imaging. Hippocampal neurons were prepared from rat as previously. ${ }^{44}$ At 7 days in vitro were treated with chondroitin sulfate conjugates $(29$ or 30$)$ at 50 $\mathrm{nM}$, or with $10 \mathrm{nM}$ of unconjugated dye (DBCO-PEG4-5/6Carboxyrhodamine 110), or with $50 \mathrm{nM}$ DMSO as indicated. After 10 days of treatment at 17 days in vitro, cells were washed twice with growth medium, fixed using $4 \%$ cold paraformaldehyde in phosphate-buffered saline and stained with Hoechst33342 (1:2000). Cells were imaged using a Zeiss LSM780 and $63 \times$ objective. Z-sections through nuclei are shown.

\section{ASSOCIATED CONTENT}

\section{S Supporting Information}

The Supporting Information is available free of charge on the ACS Publications website at DOI: 10.1021/acs.bioconjchem.8b00317.

${ }^{1} \mathrm{H}$ NMR and ${ }^{13} \mathrm{C}$ NMR spectra of $2-7,9-13,15,16$, 18, 21, 23, HRMS(ESI-TOF) spectra of 24-26, 29, 30, and 32-34 (PDF)

\section{AUTHOR INFORMATION}

\section{Corresponding Authors}

*E-mail: pamavi@utu.fi.

*E-mail: sgjadhav@ucsd.edu.

ORCID $\odot$

Pasi Virta: 0000-0002-6218-2212

\section{Notes}

The authors declare no competing financial interest.

\section{ACKNOWLEDGMENTS}

The financial support from the Academy of Finland (No: 308931) and the Finnish Cultural Foundation are acknowledged. 


\section{REFERENCES}

(1) Lauder, R. (2009) Chondroitin sulphate: a complex molecule with potential impacts on a wide range of biological systems. Complement. Ther. Med. 17, 56-62.

(2) Galtrey, C. M., and Fawcett, J. W. (2007) The role of chondroitin sulfate proteoglycans in regeneration and plasticity in the central nervous system. Brain Res. Rev. 54, 1-18.

(3) Murrey, H. E., and Hsieh-Wilson, L. C. (2008) The Chemical Neurobiology of Carbohydrates. Chem. Rev. 108, 1708-1731.

(4) Ichijo, H., Sugiura, N., and Kimata, K. (2013) Application of Chondroitin Sulfate Derivatives for Understanding Axonal Guidance in the Nervous System during Development. Polymers 5, 254-268.

(5) Swarup, V. P., Mencio, C. P., Hlady, V., and Kuberan, B. (2013) Sugar Glues for Broken Neurons. Biomol. Concepts 4 (3), 233-257.

(6) Kjellen, L., and Lindahl, U. (1991) Proteoglycans: structures and interactions. Annu. Rev. Biochem. 60, 443-475.

(7) Solera, C., Macchione, G., Maza, S., Kayser, M. M., Corzana, F., de Paz, J. L., and Nieto, P. M. (2016) Chondroitin Sulfate Tetrasaccharides: Synthesis, Three-Dimensional Structure and Interaction with Midkine. Chem. - Eur. J. 22, 2356-2369.

(8) Yamada, S., and Sugahara, K. (2008) Potential therapeutic application of chondroitin sulfate/dermatan sulfate. Curr. Drug Discovery Technol. 5, 289-301.

(9) Karst, N. A., and Linhardt, R. J. (2003) Recent chemical and enzymatic approaches to the synthesis of glycosaminoglycan oligosaccharides. Curr. Med. Chem. 10, 1993-2031.

(10) Vibert, A., Jacquinet, J.-C., and Lopin-Bon, C. (2011) Recent Advances in the Chemical and Enzymatic Chondroitin Sulfate Synthesis. J. Carbohydr. Chem. 30, 393-414.

(11) Bedini, E., and Parrilli, M. (2012) Synthetic and semi-synthetic chondroitin sulfate oligosaccharides, polysaccharides, and glycomimetics. Carbohydr. Res. 356, 75-85.

(12) Lopin, C., and Jacquinet, J.-C. (2006) From Polymer to SizeDefined Oligomers: An Expeditious Route for the Preparation of Chondroitin Oligosaccharides. Angew. Chem., Int. Ed. 45, 2574-2578.

(13) Tamura, J., Nakada, Y., Taniguchi, K., and Yamane, M. (2008) Synthesis of chondroitin sulfate $\mathrm{E}$ octasaccharide in a repeating region involving an acetamide auxiliary. Carbohydr. Res. 343, 39-47.

(14) Jacquinet, J. C., Lopin-Bon, C., and Vibert, A. (2009) From Polymer to Size-Defined Oligomers: A Highly Divergent and Stereocontrolled Construction of Chondroitin Sulfate A, C, D, E, K, L, and M Oligomers from a Single Precursor: Part 2. Chem. - Eur. J. 15, 9579-9595.

(15) Tamura, J., Tanaka, H., Nakamura, A., and Takeda, N. (2013) Synthesis of b-D-GalNAc(4,6-diS)(1-4)[a-L-Fuc(2,4-diS)(1-3)]-bD-GlcA, a novel trisaccharide unit of chondroitin sulfate with a fucose branch. Tetrahedron Lett. 54, 3940-3943.

(16) Macchione, G., Maza, S., Mar Kayser, M., de Paz, J. L., and Nieto, P. M. (2014) Synthesis of Chondroitin Sulfate Oligosaccharides Using N-(Tetrachlorophthaloyl)- and $N$-(Trifluoroacetyl)galactosamine Building Blocks. Eur. J. Org. Chem. 2014, 3868-3884.

(17) Wakao, M., Obata, R., Miyachi, K., Kaitsubata, Y., Kondo, T., Sakami, C., and Suda, Y. (2015) Synthesis of a chondroitin sulfate disaccharide library and a GAG-binding protein interaction analysis. Bioorg. Med. Chem. Lett. 25, 1407-1411.

(18) Bedini, E., De Castro, C., De Rosa, M., Di Nola, A., Iadonisi, A., Restaino, O. F., Schiraldi, C., and Parrilli, M. (2011) A Microbiological-Chemical Strategy to Produce Chondroitin Sulfate A, C. Angew. Chem., Int. Ed. 50, 6160-6163.

(19) de Paz, J.-L., Angulo, J., Lassaletta, J.-M., Nieto, P. M., RedondoHorcajo, M., Lozano, R. M., Gimenez-Gallego, G., and Martin-Lomas, M. (2001) The Activation of Fibroblast Growth Factors by Heparin: Synthesis, Structure, and Biological Activity of Heparin-Like Oligosaccharides. ChemBioChem 2, 673-685.

(20) Eller, S., Collot, M., Yin, J., Hahm, H. S., and Seeberger, P. H. (2013) Automated Solid-Phase Synthesis of Chondroitin Sulfate Glycosaminoglycans. Angew. Chem., Int. Ed. 52, 5858-5861.
(21) Tully, S. E., Mabon, R., Gama, C. I., Tsai, S. M., Liu, X., and Hsieh-Wilson, L. C. (2004) A Chondroitin Sulfate Small Molecule that Stimulates Neuronal Growth. J. Am. Chem. Soc. 126, 7736-7737.

(22) Maza, S., Mar Kayser, M., Macchione, G., Lopez-Prados, J., Angulo, J., de Paz, J. L., and Nieto, P. M. (2013) Synthesis of chondroitin/dermatan sulfate-like oligosaccharides and evaluation of their protein affinity by fluorescence polarization. Org. Biomol. Chem. $11,3510-3525$.

(23) Vibert, A., Lopin-Bon, C., and Jacquinet, J.-C. (2009) From Polymer to Size-Defined Oligomers: A Step Economy Process for the Efficient and Stereocontrolled Construction of Chondroitin Oligosaccharides and Biotinylated Conjugates Thereof: Part 1. Chem. - Eur. J. 15, 9561-9578.

(24) Vibert, A., Lopin-Bon, C., and Jacquinet, J.-C. (2011) Efficient and Stereocontrolled Construction of Homo- and Heterogeneously 4and 6-Sulfated Biotinylated Chondroitin Oligomers. Eur. J. Org. Chem. 2011, 4183-4204.

(25) Tamura, J.-I., Tsutsumishita-Nakai, N., Nakao, Y., Kawano, M. Kato, S., Takeda, N., Nadanaka, S., and Kitagawa, H. (2012) Synthesis and interaction with midkine of biotinylated chondroitin sulfate tetrasaccharides. Bioorg. Med. Chem. Lett. 22, 1371-1374.

(26) Despras, G., Bernard, C., Perrot, A., Cattiaux, L., Prochiantz, A., Lortat-Jacob, H., and Mallet, J.-M. (2013) Toward Libraries of Biotinylated Chondroitin Sulfate Analogues: From Synthesis to In Vivo Studies. Chem. - Eur. J. 19, 531-540.

(27) Jacquinet, J.-C., and Lopin-Bon, C. (2015) Stereocontrolled preparation of biotinylated chondroitin sulfate $\mathrm{E}$ di-, tetra-, and hexasaccharide conjugates. Carbohydr. Res. 402, 35-43.

(28) Rawat, M., Gama, C. I., Matson, J. B., and Hsieh-Wilson, L. C. (2008) Neuroactive Chondroitin Sulfate Glycomimetics. J. Am. Chem. Soc. 130, 2959-2961.

(29) Lee, S.-G., Brown, J. M., Rogers, C. J., Matson, J. B., Krishnamurthy, C., Rawat, M., and Hsieh-Wilson, L. C. (2010) Endfunctionalized glycopolymers as mimetics of chondroitin sulfate proteoglycans. Chem. Sci. 1, 322-325.

(30) Liu, P., Chen, L., Toh, J. K. C., Ang, Y. L., Jee, J.-E., Lim, J., Lee, S. S., and Lee, S.-G. (2015) Tailored chondroitin sulfate glycomimetics via a tunable multivalent scaffold for potentiating NGF/TrkA-induced neurogenesis. Chem. Sci. 6, 450-456.

(31) Pulsipher, A., Griffin, M. E., Stone, S. E., Brown, J. M., and Hsieh-Wilson, L. C. (2014) Directing Neuronal Signaling through Cell-Surface Glycan Engineering. J. Am. Chem. Soc. 136, 6794-6797.

(32) Miyachi, K., Wakao, M., and Suda, Y. (2015) Syntheses of chondroitin sulfate tetrasaccharide structures containing 4,6-disulfate patterns and analysis of their interaction with glycosaminoglycanbinding protein. Bioorg. Med. Chem. Lett. 25, 1552-1555.

(33) Tully, S. E., Rawat, M., and Hsieh-Wilson, L. C. (2006) Discovery of a TNF- $\alpha$ Antagonist Using Chondroitin Sulfate Microarrays. J. Am. Chem. Soc. 128, 7740-7741.

(34) Bagari, R., Bansal, D., Gulbake, A., Jain, A., Soni, V., and Jain, S. (2011) Chondroitin sulfate functionalized liposomes for solid tumor targeting. J. Drug Target 19 (4), 251-257.

(35) Lo, Y.-L., Sung, K.-H., Chiu, C.-C., and Wang, L.-F. (2013) Chemically Conjugating Polyethylenimine with Chondroitin Sulfate to Promote CD44-Mediated Endocytosis for Gene Delivery. Mol. Pharmaceutics 10, 664-676.

(36) Liu, Y.-S., Chiu, C.-C., Chen, H.-Y., Chen, S.-H., and Wang, L.F. (2014) Preparation of Chondroitin Sulfate- $g$-poly ( $\varepsilon$-caprolactone) Copolymers as a CD44-Targeted Vehicle for Enhanced Intracellular Uptake. Mol. Pharmaceutics 11, 1164-1175.

(37) Jadhav, S., Yim, C.-B., Rajander, J., Grönroos, T. J., Solin, O., and Virta, P. (2016) Solid-Supported Porphyrins Useful for the Synthesis of Conjugates with Oligomeric Biomolecules. Bioconjugate Chem. 27, 1023-1029.

(38) Jadhav, S., Käkelä, M., Mäkilä, J., Kiugel, M., Liljenbäck, H., Virta, J., Poijärvi-Virta, P., Laitala-Leinonen, T., Kytö, V., Jalkanen, et al. (2016) Synthesis and In Vivo PET Imaging of Hyaluronan Conjugates of Oligonucleotides. Bioconjugate Chem. 27, 391-403. 
(39) Yang, S., Wang, A., Zhang, G., Di, X., Zhao, Z., and Lei, P. (2016) An investigation of construction of chondroitin sulfate E (CSE) repeating unit. Tetrahedron $72,5659-5670$.

(40) Bélot, F., and Jacquinet, J.-C. (2000) Unexpected stereochemical outcome of activated 4,6-O-benzylidene derivatives of the 2deoxy-2-trichloroacetamido-d-galacto series in glycosylation reactions during the synthesis of a chondroitin 6-sulfate trisaccharide methyl glycoside. Carbohydr. Res. 325, 93-106.

(41) Qiu, D., Gandhi, S. S., and Koganty, R. (1996) $\beta$ Gal(13) GalNAc block donor for the synthesis of TF and $\alpha$ Sialy (2-6)TF as glycopeptide building blocks. Tetrahedron Lett. 37, 595-598.

(42) Morvan, F., Vidal, S., Souteyrand, E., Chevolot, Y., and Vasseur, J.-J. (2012) DNA glycoclusters and DNA-based carbohydrate microarrays: From design to applications. RSC Adv. 2, 12043-12068.

(43) Kwok, J. C. F., Yuen, Y.-L., Lau, W.-K., Zhang, F.-X., Fawcett, J. W., Chan, Y.-S., and Shum, D. K. Y. (2012) Chondroitin sulfates in the developing rat hindbrain confine commissural projections of vestibular nuclear neurons. Neural Dev. 7, 6.

(44) Tararuk, T., Östman, N., Li, W., Björkblom, B., Padzik, A., Zdrojewska, J., Hongisto, V., Herdegen, T., Konopka, W., Courtney, M., and Coffey, E. T. (2006) JNK1 phosphorylation of SCG10 determines microtubule dynamics and axodendritic length. J. Cell Biol. 173, 265-277. 